In cooperation with the Wisconsin Department of Transportation

\title{
Flood-Frequency Characteristics of Wisconsin Streams
}

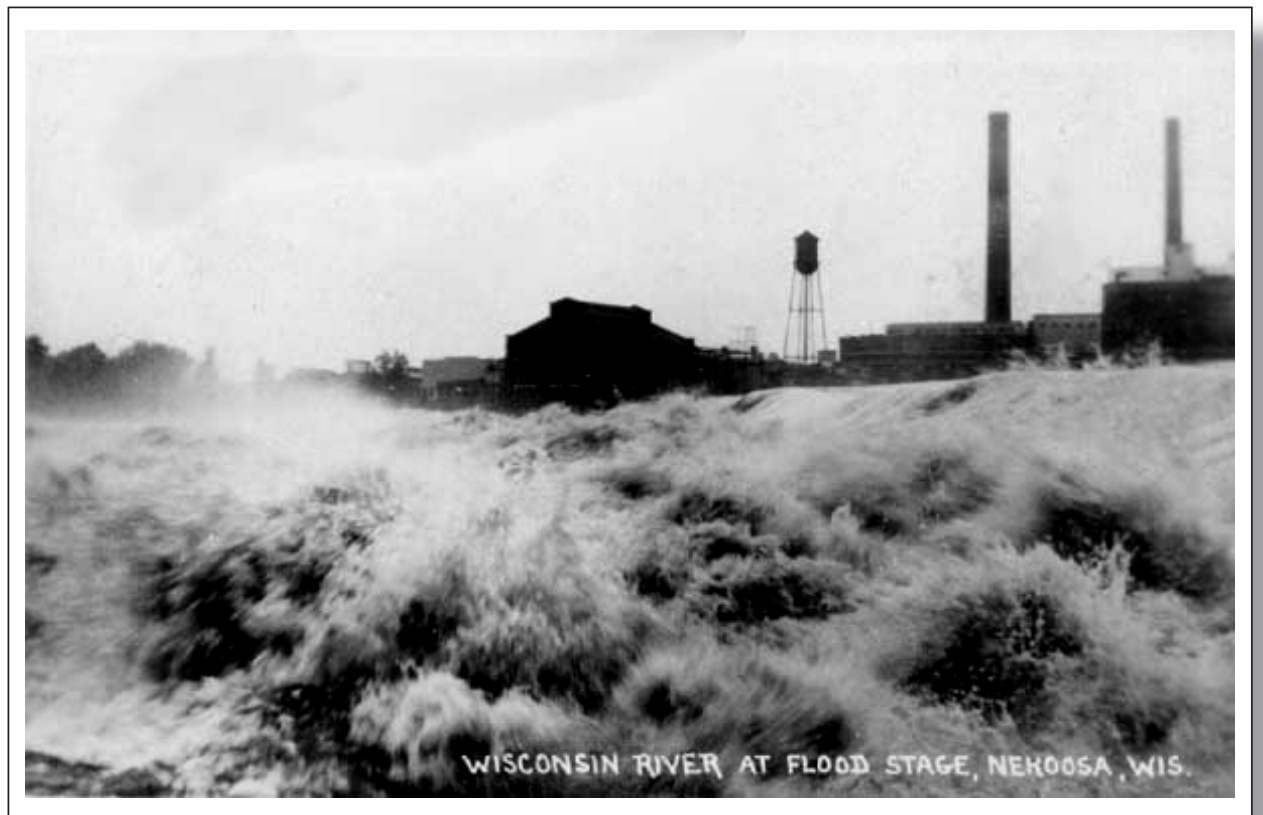

Water-Resources Investigations Report 03-4250 


\section{Flood-Frequency Characteristics of Wisconsin Streams}

By J.F. Walker and W.R. Krug

In cooperation with the Wisconsin Department of Transportation

Water-Resources Investigations Report 03-4250 


\section{U.S. Department of the Interior \\ Gale A. Norton, Secretary \\ U.S. Geological Survey \\ Charles G. Groat, Director}

U.S. Geological Survey, Reston, Virginia: 2003

For sale by U.S. Geological Survey, Information Services
Box 25286, Denver Federal Center
Denver, CO 80225
For more information about the USGS and its products:
Telephone: 1-888-ASK-USGS
World Wide Web: http://www.usgs.gov/

Any use of trade, product, or firm names in this publication is for descriptive purposes only and does not imply endorsement by the U.S. Government. 


\section{Contents}

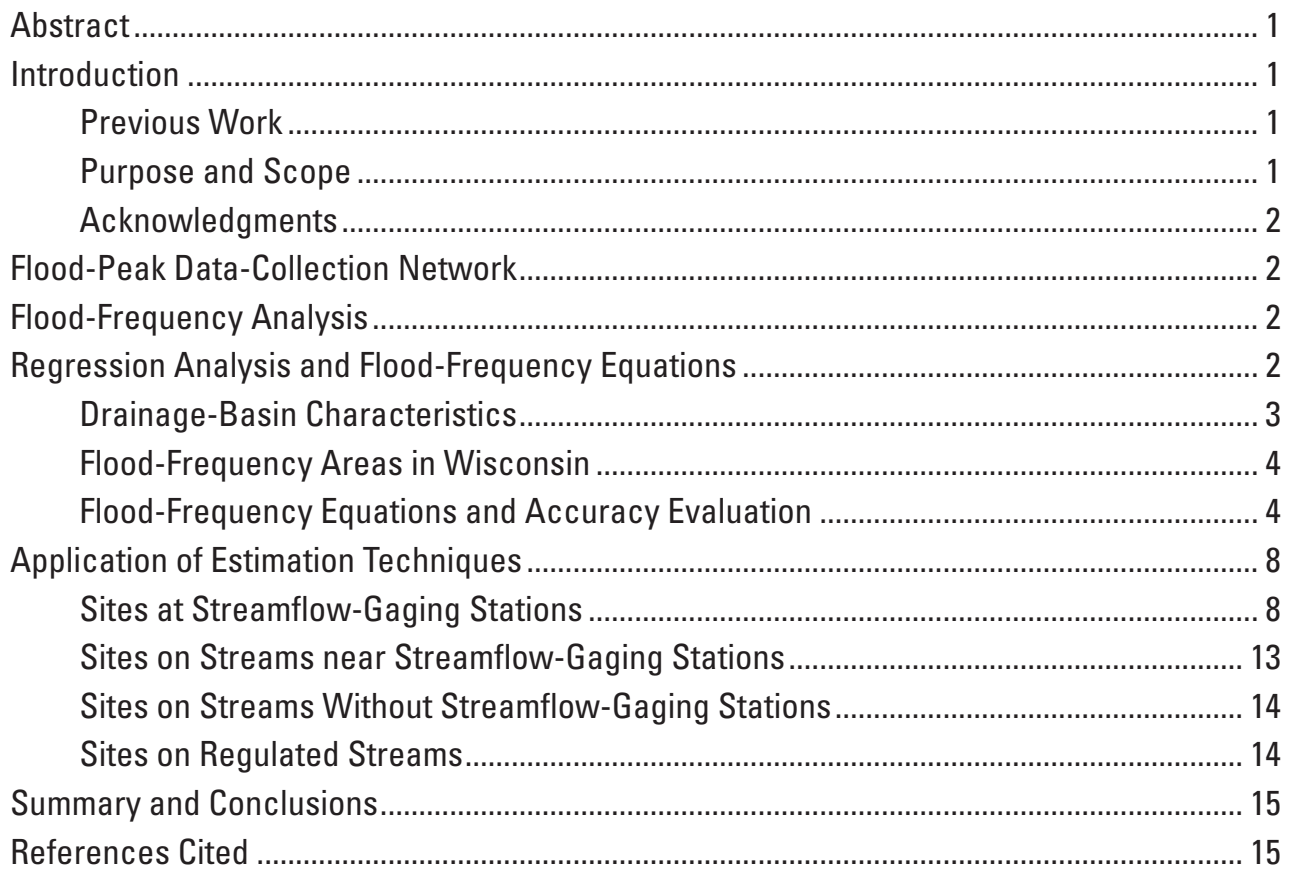

\section{Plates}

1. Map of Wisconsin showing location of streamflow-gaging stations, crest-stage partial-record stations, and regulation stations .......................... in envelope

2. Map of Wisconsin showing soil permeability ................................................. in envelope

\section{Figures}

1-3. Maps showing:

1. 25-year, 24-hour rainfall in Wisconsin by climatic section................................... 5

2. Mean annual snowfall from 1961 through 1990 in Wisconsin ............................ 6

3. Flood-frequency areas in Wisconsin............................................................. 7

4-7. Graphs showing relation of discharge to drainage area for selected flood frequencies along the main stem of the:

4. Menominee River, Wisconsin and Michigan................................................... 12

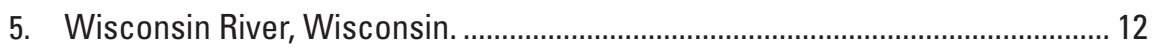

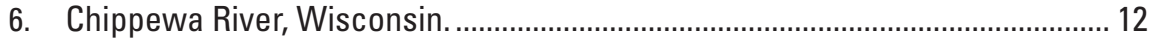

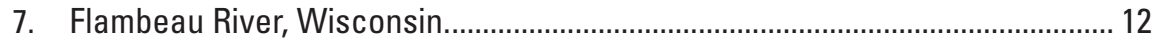




\section{Tables}

1. Comparison of regression results for ordinary least squares (OLS) and

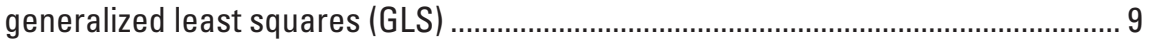

2. Flood-frequency equations for streams in Wisconsin ........................................... 10

3. Ranges of basin characteristics used in regression analysis .................................. 11

\section{Appendix}

A-1. Flood discharges at selected recurrence intervals and WRC skew for streamflow-gaging stations in the Wisconsin flood-frequency network

A-2. Drainage-basin characteristics for rural streamflow-gaging stations in Wisconsin 


\title{
Flood-Frequency Characteristics of Wisconsin Streams
}

\author{
By J.F. Walker and W.R. Krug
}

\begin{abstract}
Flood-frequency characteristics for 312 gaged sites on Wisconsin streams are presented for recurrence intervals of 2 to 100 years using flood-peak data collected through water year 2000. Equations of the relations between floodfrequency and drainage-basin characteristics were developed by multiple-regression analyses. Flood-frequency characteristics for ungaged sites on unregulated, rural streams can be estimated by use of these equations. The state was divided into five areas with similar physiographic characteristics. The most significant basin characteristics are drainage area, main-channel slope, soil permeability, storage, rainfall intensity, and forest cover. The standard error of prediction for the equation for the 100-year flood discharge ranges from 22 to 44 percent in the state. A graphical method for estimating flood-frequency characteristics of regulated streams was developed from the relation of discharge and drainage area. Graphs for the major regulated streams are presented.
\end{abstract}

\section{Introduction}

Flood-frequency information is needed for the design of bridges, culverts, highways, flood-protection structures, and for effective flood-plain management. This study was done in cooperation with the Wisconsin Department of Transportation. This report is the fifth within a long-term study of flood-frequency characteristics of Wisconsin streams. Collectively these studies make up what is referred to as the flood-frequency project.

\section{Previous Work}

The first report in the series (Ericson, 1961) developed two sets of regression equations (with and without channel slope as a parameter) for several geographic areas in the state. The second report in the series (Conger, 1971) updated the original report by including additional flood- peak data, refining the geographic areas, and including snowfall as an independent variable. The next version of the report (Conger, 1981) included updated flood-peak data, refined the geographic areas, and added rainfall intensity as an independent variable. The fourth incarnation of the report (Krug and others, 1992) included updated flood-peak data, provided further refinement of the geographic areas, and included an evaluation of alternative land-use data and various regionalization techniques. Other reports that include methods for estimating flood-frequency characteristics of Wisconsin streams were done by Wiitala (1965) and Patterson and Gamble (1968). This report uses the same geographic areas as in the previous report (Krug and others, 1992), includes additional flood-peak data, and updates the values for snowfall and rainfall intensity. Additional data used in this report increase the confidence in estimating techniques and supersede those published in previous reports.

\section{Purpose and Scope}

This report includes a description of flood-frequency characteristics of Wisconsin streams where annual peak streamflow data have been collected, presents equations for estimating flood-frequency characteristics at ungaged sites, and includes a discussion of the development of the equations. Additional flood-peak data were collected at the crestgage stations at most of the same sites as previous studies, with the data-collection period ending in 2000 . These stations help provide a uniform distribution of sites throughout the state and a long-term record of flood-peak data.

Because operation of continuous-record streamflowgaging stations is not part of the flood-frequency project, the locations and lengths of record at these sites are controlled by other needs. Therefore, the distribution and lengths of record are not as uniform as at crest-gage sites. Continuous-record flood-peak data in this study were collected at 175 streamflow-gaging stations whereas the data used by Conger (1981) were collected at 78 stations. 


\section{Acknowledgments}

Mari Dantz and Bernard Lenz of the Wisconsin District Office of the U.S. Geological Survey (USGS) were instrumental in updating rainfall and snowfall data and performing some of the preliminary regression analyses.

\section{Flood-Peak Data-Collection Network}

Flood-peak data used in this study were collected at 137 crest-gage stations and 175 continuous-record streamflow-gaging stations located throughout the state (plate 1). Only the peak stage of a flood is recorded at a crest-stage station. The recorded maximum stage for each year is converted to discharge by a stage-discharge relation for each station. At continuous-record streamflow-gaging stations, a continuous record of stream stage is recorded. The maximum stage for the year is selected and is converted to discharge by a stage-discharge relation. Stations with at least 10 years of record located on rural streams were included. On the basis of these criteria, 312 stations were included in the report. Flood-peak data are available for 104 crest-gage stations and for 108 streamflow-gaging stations now operated (2000) and from 33 crest-gage stations and 67 streamflow-gaging stations that have been discontinued. Of the continuous-record stations, 32 are on streams that are regulated. Sites were classified as regulated based on knowledge of the flow system and hydrologic judgement. The 104 crest-gage stations are operated as part of the flood-frequency project. Most of the crest gages have been operated since the late 1950's or early 1960's. Several stations started to operate around 1970 in northeastern Wisconsin when the first analysis of the data showed the need for more data in this area. Data through the 2000 water year were used for the analysis in this report. Therefore, at least 28 years of flood-peak data were used for most stations; however, about 18 years of flood-peak data were used for some stations in the northeastern part of the state.

Annual peak stages and discharges for all crest-gage stations and streamflow-gaging stations used in the study are available by request from the Wisconsin District Office of USGS or from the world-wide-web on the internet via the following URL: http://waterdata.usgs.gov/wi/nwis/ peak.

\section{Flood-Frequency Analysis}

Flood-frequency analyses define the relation of floodpeak magnitude to probability of exceedance or recurrence interval. Probability of exceedance is the percentage chance that a given flood magnitude will be exceeded in any year. Recurrence interval is the reciprocal of percent probability of exceedance divided by 100 and is the average number of years between exceedances. For example, a flood having a probability of exceedance of 1 percent has a recurrence interval of 100 years. Recurrence intervals imply no regularity of exceedance; a 100-year flood might be exceeded in consecutive years or it might not be exceeded in a 100-year period.

Flood-frequency analyses were performed at all rural streamflow-gaging stations with a period of record equal to or exceeding 10 years. Guidelines in Interagency Advisory Committee on Water Data (1982)(commonly referred to as Bulletin 17B) were used to fit logarithms of annual peak discharges to the Pearson Type III distribution. For stations on unregulated streams, the generalized skew from the map in Bulletin 17B was weighted with the station skew to give a weighted skew. Estimates of discharges at several recurrence intervals in the range from 2 to 100 years for each station were computed and are given in Appendix table A-1.

Sites on the main stem of the Wisconsin River received additional analyses. Krug and House (1980) modeled the system of reservoirs and their operation to simulate the flood peaks on the Wisconsin River for water years 1915 through 1976. The flood frequencies given for the Wisconsin River in this study (Appendix table A-2) include the simulated peaks (Krug and House, 1980, Appendix B) and the observed peaks for water years 1977 through 2000. These flood frequencies are considered the most up-to-date estimates of the flood potential of the existing system of reservoirs and their operating policies.

\section{Regression Analysis and Flood- Frequency Equations}

Multiple-regression analysis was used to estimate the relation between flood discharges for given frequencies and drainage-basin characteristics for 200 selected streamflow-gaging stations in Wisconsin. The sites selected, which were the same as those used by Krug and others (1992), were rural, unregulated sites with at least 10 years of record and known basin characteristics. The multiple 
regression technique is a means of transferring flood-peak characteristics from sites where observed data are available to ungaged locations. The relation is presented by floodfrequency equations.

The regression equations are used to relate the most significant drainage-basin characteristics (independent variables) to flood-peak characteristics (dependent variables; $\mathrm{Q}_{2}, \mathrm{Q}_{5} \ldots, \mathrm{Q}_{100}$ ). The multiple-regression model can be expressed in the following form:

$$
Q_{T}=\alpha A^{a} B^{b} C^{c} \ldots M^{m}
$$

where

$$
\begin{array}{ll}
Q_{T} & \begin{array}{l}
\text { is flood magnitude, in cubic feet per } \\
\text { second, having a T-year recurrence }
\end{array} \\
& \text { interval; } \\
\alpha & \text { is regression constant defined by } \\
& \text { regression analysis; }
\end{array}
$$
$A, B, C, \ldots M$
are basin characteristics; and
$a, b, c, \ldots m$
are regression coefficients defined
by regression analysis.

This form of the multiple-regression model is achieved by linear regression of the logarithms of the variables.

The principal method of regression analysis used in the study is called generalized least squares (GLS) and was developed by Tasker and others (1986) and Stedinger and Tasker (1985). This method was used because of its theoretical advantages over the ordinary least squares (OLS) method and the conventional weighted least squares (WLS) method.

In the OLS method, all the estimates of T-year floods are implicitly assumed to have equal variance; that is, the T-year flood estimate at each streamflow-gaging station is assumed to be as accurate as the T-year flood estimates at all other stations used in the regression, regardless of record length and site variability. Furthermore, in the OLS method, the concurrent flood peaks at different sites are assumed to be uncorrelated or independently distributed. In general, these two conditions are not met by flood-peak records. The accuracy of the T-year flood estimates varies with the length of record and variability of the annual peak discharges at each site. Many concurrent annual floods in an area are cross-correlated because the stations in the area are subject to similar weather systems.

In the GLS method, the variable accuracy of the T-year flood estimates and the cross-correlation between stations are considered. With this method, information is provided for analyzing the network of streamflow-gaging stations and crest gages. This network analysis capability may prove to be useful in future studies.

\section{Drainage-Basin Characteristics}

The drainage-basin characteristics determined by the multiple-regression analyses to be significant were drainage area, main-channel slope, storage, forest cover, 25-year precipitation index, mean annual snowfall, and soil permeability. The characteristics used in the regression equations are listed in Appendix table A-2 at the back of this report for each station. They are defined as follows:

1. Drainage area $(A)$, in square miles, is the area contributing directly to surface runoff. This area can be planimetered from topographic maps or can be taken directly for some sites from the report on drainage ares in Wisconsin by Henrich and Daniel (1983). If the drainage area is taken from the report by Henrich and Daniel, any area not contributing directly to surface runoff should be subtracted from the total drainage area.

2. Main-channel slope $(S)$, in feet per mile, is the slope of the stream between points that are 10 percent and 85 percent of the distance along the channel from the streamflow-gaging station to the basin divide, determined from topographic maps.

3. Storage (ST), expressed as a percentage of the drainage area, includes lakes, ponds, and wetlands determined from USGS maps and Soil Conservation Service data. A constant of 1 percent is added to storage to obtain $S T$ (to avoid zero values in the regression equations).

4. Forest cover $(F O R)$ is expressed as a percentage of the drainage area shown on USGS maps, determined by the grid method, or is data from the Soil Conservation Service. A constant of 1 percent is added to forest cover to obtain FOR (to avoid zero values in the regression equations).

5. The 25-year precipitation index $\left(I_{25}\right)$ is computed by subtracting 4.2 from the 25-year, 24-hour rainfall, expressed in inches (Huff and Angel, 1992). The maximum 25-year, 24-hour rainfall has a recurrence interval of 25 years. Precipitation indices were computed for recurrence intervals of 2-, 10-, 25-, 50- and 100 -years. The 25 -year recurrence interval subsequently proved to be the best precipitation index for predicting the selected recurrence-interval flood discharges. The 25-year, 24-hour rainfall amounts for 
the 9 climatic sections in Wisconsin (Huff and Angel, 1992) are shown in figure 1 . Values of $I_{25}$ were determined at each streamflow-gaging station.

6. Mean annual snowfall $(S N)$ for 1961 through 1990, in inches, is determined from climate data processed by the Spatial Climate Analysis Service at Oregon State University (Daly and others, 2000) and is shown in figure 2. $S N$ is interpolated from the contours for the location of the streamflow-gaging station.

7. Soil permeability $(S P)$, in inches per hour, is based on the least-permeable soil horizon in the soil column.

The median rate is used for each range of soil permeability. Ranges of soil permeability were obtained from a soils table published by the U.S. Department of Agriculture, Soil Conservation Service (1964) and overlaid on a soils map of Wisconsin (Hole and others, 1968). The weighted-average soil permeability $(S P)$ is shown on plate 2 . A grid is printed on the back of plate 2 to facilitate estimating the percent of the basin in each soil-permeability range.

\section{Flood-Frequency Areas in Wisconsin}

The state was divided into five flood-frequency areas by Conger (1981). Several boundaries between areas were adjusted in north-central Wisconsin on the basis of physical characteristics (Krug and others, 1992) and residuals from the regression equations when applied to particular sites (fig. 3 and pl. 1).

The five-area arrangement of the state is useful in reducing the errors in the regression equations. Different basin characteristics are significant in estimating the flood frequency in the various areas. For example, soil permeability is not a significant variable in flood-frequency equations for the southern part of the state (areas 1 and 5), but it is significant in the central and northern parts of the state (areas 2, 3 and 4). Note that the driftless area is contained almost entirely in area 1 (plate 1 and fig. 3).

\section{Flood-Frequency Equations and Accuracy Evaluation}

For this study, a combination of OLS and GLS regressions was used to determine the best-fit regression equations for each flood-frequency area (fig. 3). A stepwise OLS procedure was used as a screening tool to determine the suite of variables that best predicted the T-year flood for each area. The stepwise procedure selects a subset of variables from a group of candidate basin characteristics (as described in the previous section) beginning with the variable that explains the most variability in the dependent variable, and continues with each successive variable that explains the most remaining variability given the effects of the variables already chosen. A variable was selected when its coefficient was determined to be significantly different from zero at the 5-percent level (significance level less than 0.05).

To facilitate comparison of various regressions, the standard error of estimate was used (a measure of the error in the use of regression equations to predict T-year floods at sites used in the regression analysis). Because the regression equations were computed using a logarithmic transformation of the dependent and independent variables, the standard error in log space was used to determine confidence intervals for predictions of the logarithm of a particular T-year discharge. The true value of the log of the T-year flood will be within plus or minus one standard error of the regression estimate at about two-thirds of the sites. Because of the nonlinear nature of the logarithmic transformation, the resulting confidence intervals transformed to actual discharges are not symmetrical. For comparison purposes, an "equivalent" standard error as a percent of predicted discharge was computed as follows:

$$
E S E=\frac{10^{S E}-10^{-S E}}{2}
$$

where

$$
\begin{array}{ll}
\text { ESE } & \text { is the equivalent standard error in } \\
\text { percent of predicted discharge, and } \\
\text { SE the standard error of the logarithm of } \\
\text { discharge. }
\end{array}
$$

Note that the ESE essentially results in a confidence interval that has the same width as the true confidence interval for two-thirds of the predicted values; however, the upper and lower bounds computed with the ESE will not be correct because of the asymmetry of the confidence intervals.

For most areas, the stepwise procedure results in a slightly different set of independent variables for each of the T-year floods (2-, 5-, 10-, 25-, 50- and 100-year). To maintain consistency, a common set of variables was chosen to predict each of the T-year floods in a particular area; in general, the set of variables explaining the most variability of the higher recurrence interval floods (50and 100-year) was chosen. This set of variables was then used to estimate the regressions using the GLS procedure. Selecting a set of variables that deviates from the stepwise results will produce a somewhat diminished accuracy of prediction for the regression. To illustrate the differences 


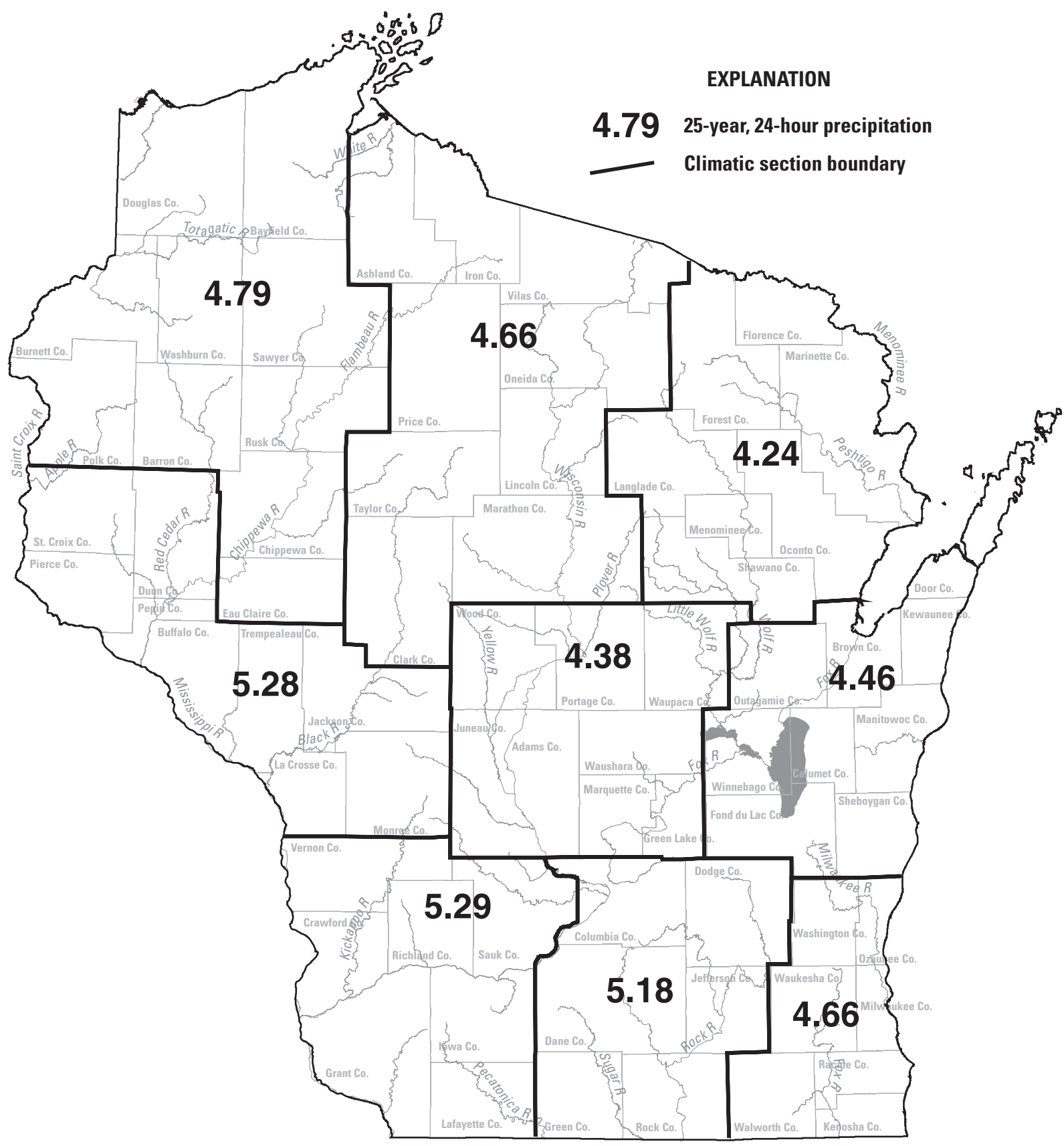

Base from Wisconsin Department of Natural Resources 1:100,000 digital data, 1998.

Wisconsin Transverse Mercator Projection

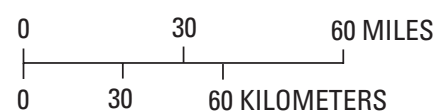

Figure 1. 25-year, 24-hour rainfall in Wisconsin by climatic section (rainfall data from Huff and Angel, 1992). 


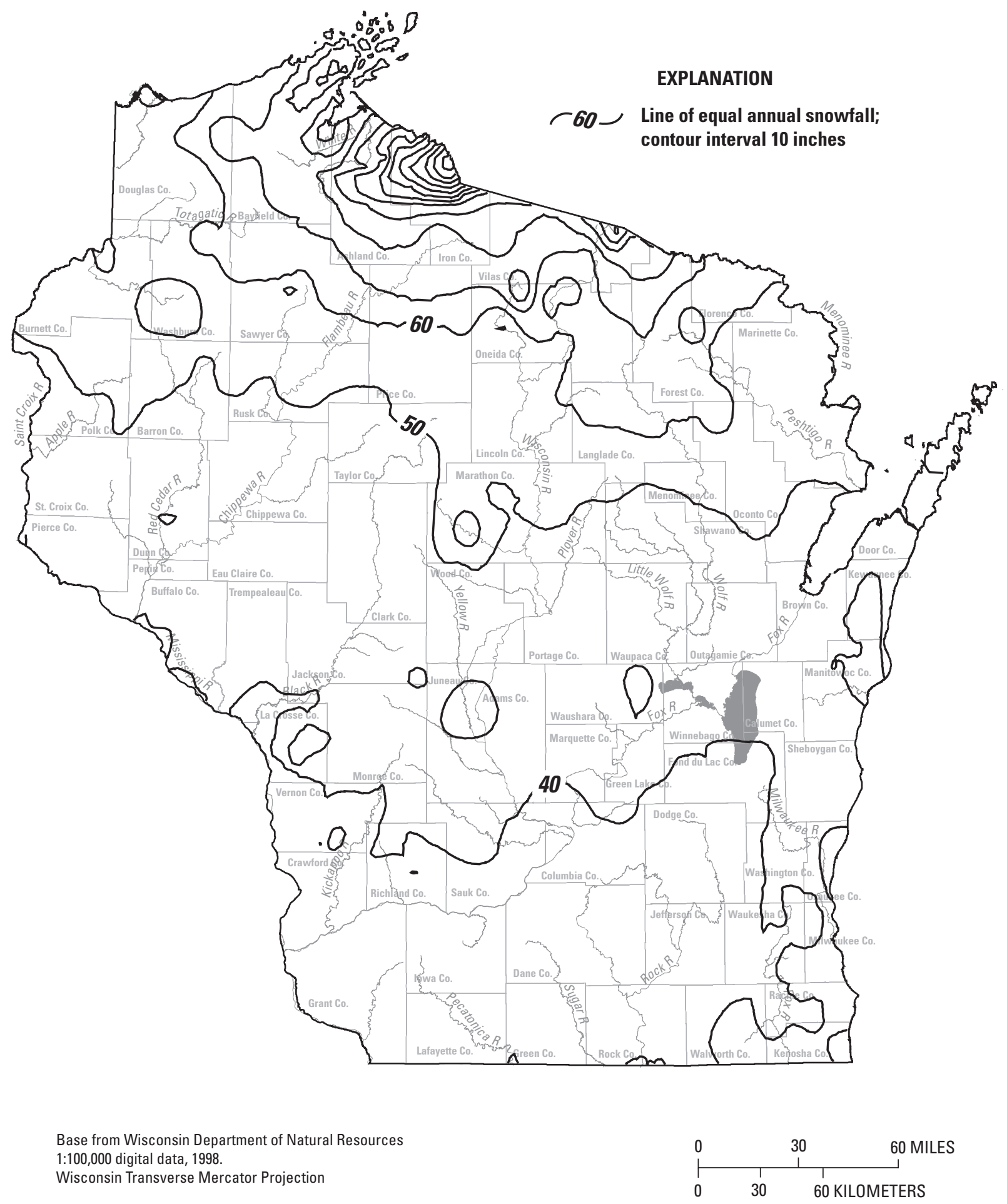

Figure 2. Mean annual snowfall from 1961 through 1990, in inches, in Wisconsin (snowfall data from Daly and others, 2000). This map contains data from the Climate Source, and is used herein by permission. Copyright (c) 2000 The Climate Source, www.climatesource.com. All rights reserved. 


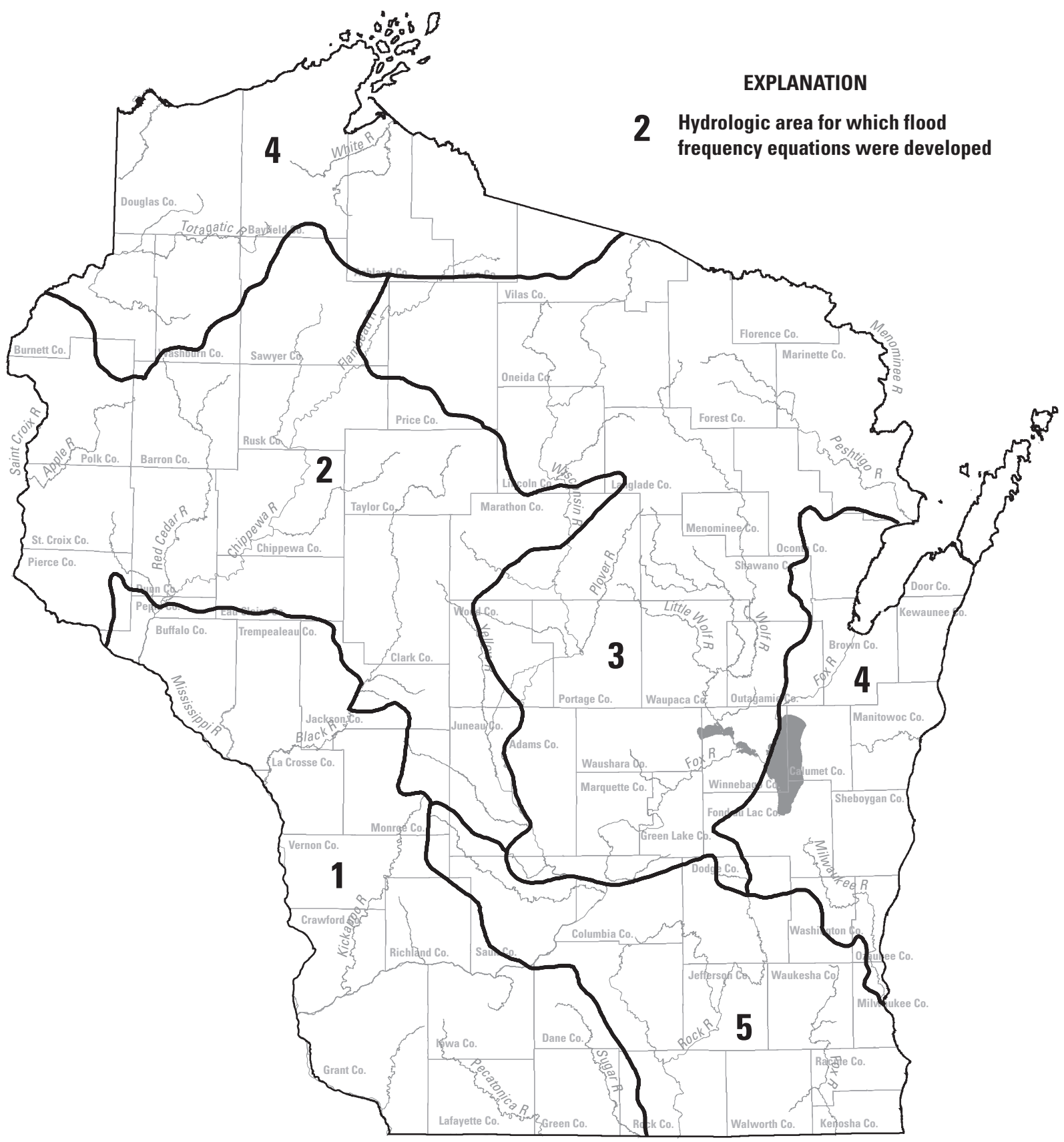

Base from Wisconsin Department of Natural Resources 1:100,000 digital data, 1998.

Wisconsin Transverse Mercator Projection

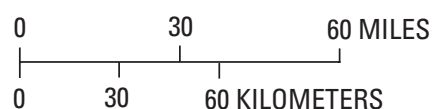

Figure 3. Flood-frequency areas in Wisconsin. 
in model accuracy, the estimated standard errors in log space (approximated by the model error) and an equivalent standard error of estimate in percent were determined for three separate regressions: (1) the best set of variables using OLS stepwise estimation, (2) a common set of variables using OLS regression; and (3) a common set of variables using GLS regression (table 1). For the most part, the increase in standard error for the common set of variables is relatively small, and in some cases is compensated for by the improvements afforded by the GLS procedure.

The flood-frequency equations developed for streams in Wisconsin, along with the standard error of estimate in log space and equivalent standard error of estimate in percent are presented in table 2 . The equivalent standard error of estimate is shown for comparison with similar data published in previous reports (Conger, 1971 and 1981; Krug and others, 1992); however, it is computed differently in this study and the comparison is not exact. The standard error of estimate for the regression equations for the 100-year flood in the Conger (1971) report ranged from 37 to 41 percent. The comparable range of standard error of prediction was 35 to 40 percent in the Conger (1981) report. The range of standard error of prediction for the 100-year flood was 22 to 33 percent in the Krug and others (1992) report. The range of standard error of prediction for the 100-year flood in table 3 is 22 to 44 percent.

The biggest discrepancy between the equivalent standard errors in the previous report and this report occur for the most part in areas 1 and 5 (fig. 3), which constitute a large portion of the driftless area. Recent evidence indicates that floods in the driftless area of the state have been decreasing over time (Gebert and Krug, 1996). The issue of stationarity in the record is beyond the scope of this study; however, it is a likely topic to be considered in the next revision of the regression equations.

The regression equations are valid for streams without significant regulation. For the purposed of this report, a dam on a stream or river does not constitute regulation unless the dam is used to control the flow during a flood.

The regression equations and the associated accuracy are considered valid only within the area for which they were developed and only for basin-characteristic values that are within the range used to calculate the regression equations. Flood estimates can be made using basin characteristics outside the range of values from which the equations were derived, but it is not possible to estimate the error in those values. The ranges of the basin characteristics of the streamflow-gaging stations used in the regression analysis are summarized in table 3.

\section{Application of Estimation Techniques}

The estimation techniques in this report can be applied to four types of rural sites. The first case is where the site is at a streamflow-gaging station; for this case, a weighted estimate is calculated based on the gaging record and the appropriate regression equation. The second case is where the site is near a streamflow-gaging station; for this case, the discharge from the appropriate regression equation is adjusted using information from the station. The third case is where there is no streamflow-gaging station on the stream; for this case, the appropriate regression equation is applied directly. The fourth case is where the site is on a regulated stream; for this case, the discharge is estimated based on drainage area and the appropriate relation for the particular regulated stream (figs. 4-7). A detailed description for applying each technique is given in the examples that follow. To estimate flood frequencies for urban streams, the reader is referred to Conger (1986).

\section{Sites at Streamflow-Gaging Stations}

Flood-frequency characteristics of sites at streamflow-gaging stations can be estimated from the station streamflow record and by the regression equations. The two methods can be considered independent when a large number of sites were used to develop the regression equations. This is because the influence of a given station on determining the regression equations is roughly inversely proportional to the number of stations used to determine the equations. When independent flood-frequency estimates are available, the Interagency Committee Advisory Committee on Water Data (1982, Appendix 8) recommends that the weighted average of the estimates be used as the best estimate of the flow frequency. If the estimates are weighted in inverse proportion to their variances, the variance of the weighted average will be less than the variance of either of the independent estimates. Flood-frequency characteristics estimated from flood-peak data are listed in Appendix table A-1. 
Table 1. Comparison of regression results for ordinary least squares (OLS) and generalized least squares (GLS)

[SE, standard error of estimate in log units; ESE, equivalent standard error of estimate in percent; Best, results using stepwise OLS regression; Common, results using OLS and a common set of independent variables; $\mathrm{Q}_{n}$, the $n$-year recurrence interval flood. Flood frequency areas are shown in figure 3.]

\begin{tabular}{|c|c|c|c|c|c|c|}
\hline \multirow{2}{*}{$\begin{array}{c}\text { Flood } \\
\text { discharge }\end{array}$} & \multicolumn{2}{|c|}{ OLS SE } & \multirow{2}{*}{$\begin{array}{l}\text { GLS SE } \\
\text { Common }\end{array}$} & \multicolumn{2}{|c|}{ OLS ESE } & \multirow{2}{*}{$\begin{array}{l}\text { GLS ESE } \\
\text { Common }\end{array}$} \\
\hline & Best & Common & & Best & Common & \\
\hline \multicolumn{7}{|c|}{ Area 1} \\
\hline $\mathrm{Q}_{2}$ & 0.1867 & 0.1867 & 0.1803 & 44 & 44 & 43 \\
\hline $\mathrm{Q}_{5}$ & .1692 & .1787 & .1709 & 40 & 42 & 40 \\
\hline $\mathrm{Q}_{10}$ & .1591 & .1746 & .1631 & 37 & 41 & 38 \\
\hline $\mathrm{Q}_{25}$ & .1852 & .1852 & .1691 & 44 & 44 & 40 \\
\hline $\mathrm{Q}_{50}$ & .1690 & .1963 & .1764 & 40 & 47 & 42 \\
\hline $\mathrm{Q}_{100}$ & .1777 & .2090 & .1855 & 42 & 50 & 44 \\
\hline \multicolumn{7}{|c|}{ Area 2} \\
\hline $\mathrm{Q}_{2}$ & .1123 & .1182 & .1091 & 26 & 28 & 25 \\
\hline $\mathrm{Q}_{5}$ & .1117 & .1207 & .1086 & 26 & 28 & 25 \\
\hline $\mathrm{Q}_{10}$ & .1157 & .1253 & .1086 & 27 & 29 & 25 \\
\hline $\mathrm{Q}_{25}$ & .1233 & .1327 & .1100 & 29 & 31 & 26 \\
\hline $\mathrm{Q}_{50}$ & .1300 & .1387 & .1118 & 30 & 32 & 26 \\
\hline $\mathrm{Q}_{100}$ & .1380 & .1458 & .1153 & 32 & 34 & 27 \\
\hline \multicolumn{7}{|c|}{ Area 3} \\
\hline $\mathrm{Q}_{2}$ & .1569 & .1626 & .1591 & 37 & 38 & 37 \\
\hline $\mathrm{Q}_{5}$ & .1489 & .1518 & .1470 & 35 & 36 & 34 \\
\hline $\mathrm{Q}_{10}$ & .1495 & .1515 & .1449 & 35 & 36 & 34 \\
\hline $\mathrm{Q}_{25}$ & .1522 & .1525 & .1439 & 36 & 36 & 34 \\
\hline $\mathrm{Q}_{50}$ & .1547 & .1547 & .1446 & 36 & 36 & 34 \\
\hline $\mathrm{Q}_{100}$ & .1580 & .1581 & .1466 & 37 & 37 & 34 \\
\hline \multicolumn{7}{|c|}{ Area 4} \\
\hline $\mathrm{Q}_{2}$ & .1305 & .1305 & .1233 & 31 & 31 & 29 \\
\hline $\mathrm{Q}_{5}$ & .1177 & .1238 & .1131 & 27 & 29 & 26 \\
\hline $\mathrm{Q}_{10}$ & .1153 & .1213 & .1063 & 27 & 28 & 25 \\
\hline $\mathrm{Q}_{25}$ & .1197 & .1197 & .0995 & 28 & 28 & 23 \\
\hline $\mathrm{Q}_{50}$ & .1203 & .1203 & .0964 & 28 & 28 & 22 \\
\hline $\mathrm{Q}_{100}$ & .1226 & .1226 & .0954 & 29 & 29 & 22 \\
\hline \multicolumn{7}{|c|}{ Area 5} \\
\hline $\mathrm{Q}_{2}$ & .1069 & .1248 & .1179 & 25 & 29 & 27 \\
\hline $\mathrm{Q}_{5}$ & .1113 & .1214 & .1127 & 26 & 28 & 26 \\
\hline $\mathrm{Q}_{10}$ & .1306 & .1306 & .1196 & 31 & 31 & 28 \\
\hline $\mathrm{Q}_{25}$ & .1494 & .1494 & .1349 & 35 & 35 & 32 \\
\hline $\mathrm{Q}_{50}$ & .1655 & .1655 & .1490 & 39 & 39 & 35 \\
\hline $\mathrm{Q}_{100}$ & .1821 & .1821 & .1637 & 43 & 43 & 39 \\
\hline
\end{tabular}


Table 2. Flood-frequency equations for streams in Wisconsin

[A, contributing drainage area in square miles; $\mathrm{S}$, main-channel slope in feet per mile; $\mathrm{I}_{25}, 25$-year, 24-hour precipitation intensity, in inches minus 4.2; ST, storage, in percent of basin area plus 1.0; SP, soil permeability of the least-permeable soil horizon in inches per hour; SN, mean annual snowfall for 1961 through 1990 in inches; FOR, forest cover in percent of basin area plus 1; $\mathrm{Q}_{n}$, peak flood discharge in cubic feet per second, with an $n$-year recurrence interval; SE, standard error of estimate of regression, in log units; ESE, equivalent standard error of estimate, in percent. Flood frequency areas are shown in figure 3.]

\begin{tabular}{|c|c|c|c|c|c|c|c|c|c|}
\hline \multicolumn{7}{|c|}{ Best-fit equation } & SE & ESE & Eq. no. \\
\hline \multicolumn{10}{|c|}{ Area 1 (39 stations) } \\
\hline$Q_{2}$ & $=$ & $99.9 A^{0.652}$ & $F O R^{-0.254}$ & $I_{25}^{7.52}$ & & & 0.1803 & 43 & $1-1$ \\
\hline$Q_{5}$ & $=$ & $190.0 A^{0.634}$ & $F O R^{-0.260}$ & $I_{25}^{8.45}$ & & & .1709 & 40 & $1-2$ \\
\hline$Q_{10}$ & $=$ & $35.0 A^{0.857}$ & $S^{0.463}$ & $F O R^{-0.302}$ & $I_{25}{ }^{6.92}$ & & .1631 & 38 & $1-3$ \\
\hline$Q_{25}$ & $=$ & $38.1 A^{0.876}$ & $S^{0.518}$ & $F O R^{-0.308}$ & $I_{25}^{7.16}$ & & .1691 & 40 & $1-4$ \\
\hline$Q_{50}$ & $=$ & $41.4 A^{0.884}$ & $S^{0.545}$ & $F O R^{-0.310}$ & $I_{25}^{7.36}$ & & .1764 & 42 & $1-5$ \\
\hline$Q_{100}$ & $=$ & $44.2 \mathrm{~A}^{0.893}$ & $S^{0.571}$ & $F O R^{-0.312}$ & $I_{25}^{7.56}$ & & .1855 & 44 & $1-6$ \\
\hline \multicolumn{10}{|c|}{ Area 2 (36 stations) } \\
\hline$Q_{2}$ & $=$ & $13.0 A^{0.884}$ & $S P^{-0.630}$ & $S^{0.382}$ & & & .1091 & 25 & $2-1$ \\
\hline$Q_{5}$ & $=$ & $15.4 A^{0.900}$ & $S P^{-0.682}$ & $S^{0.486}$ & & & .1086 & 25 & $2-2$ \\
\hline$Q_{10}$ & $=$ & $16.3 A^{0.910}$ & $S P^{-0.710}$ & $S^{0.541}$ & & & .1086 & 25 & $2-3$ \\
\hline$Q_{25}$ & $=$ & $17.3 A^{0.922}$ & $S P^{-0.740}$ & $S^{0.600}$ & & & .1100 & 26 & $2-4$ \\
\hline$Q_{50}$ & $=$ & $17.9 A^{0.929}$ & $S P^{-0.758}$ & $S^{0.636}$ & & & .1118 & 26 & $2-5$ \\
\hline$Q_{100}$ & $=$ & $18.3 A^{0.936}$ & $S P^{-0.775}$ & $S^{0.669}$ & & & .1153 & 27 & $2-6$ \\
\hline \multicolumn{10}{|c|}{ Area 3 (57 stations) } \\
\hline$Q_{2}$ & $=$ & $36.5 A^{0.832}$ & $S P^{-0.614}$ & $S T^{-0.143}$ & $I_{25}^{0.124}$ & & .1591 & 37 & $3-1$ \\
\hline$Q_{5}$ & $=$ & $61.6 A^{0.827}$ & $S P^{-0.683}$ & $S T^{-0.169}$ & $I_{25}^{0.133}$ & & .1470 & 34 & $3-2$ \\
\hline$Q_{10}$ & $=$ & $80.6 A^{0.825}$ & $S P^{-0.713}$ & $S T^{-0.186}$ & $I_{25}^{0.135}$ & & .1449 & 34 & $3-3$ \\
\hline$Q_{25}$ & $=$ & $107.0 A^{0.821}$ & $S P^{-0.743}$ & $S T^{-0.204}$ & $I_{25}^{0.136}$ & & .1439 & 34 & $3-4$ \\
\hline$Q_{50}$ & $=$ & $127.0 A^{0.819}$ & $S P^{-0.761}$ & $S T^{-0.215}$ & $I_{25}{ }^{0.136}$ & & .1446 & 34 & $3-5$ \\
\hline$Q_{100}$ & $=$ & $149.0 A^{0.818}$ & $S P^{-0.775}$ & $S T^{-0.227}$ & $I_{25}{ }^{0.136}$ & & .1466 & 34 & $3-6$ \\
\hline \multicolumn{10}{|c|}{ Area 4 (40 stations) } \\
\hline$Q_{2}$ & $=$ & $2.69 A^{0.864}$ & $S T^{-0.296}$ & $S^{0.279}$ & $S P^{-0.250}$ & $S N^{0.490}$ & .1233 & 29 & $4-1$ \\
\hline$Q_{5}$ & $=$ & $6.76 A^{0.858}$ & $S T^{-0.286}$ & $S^{0.303}$ & $S P^{-0.259}$ & $S N^{0.370}$ & .1131 & 26 & $4-2$ \\
\hline$Q_{10}$ & $=$ & $9.74 A^{0.856}$ & $S T^{-0.286}$ & $S^{0.321}$ & $S P^{-0.255}$ & $S N^{0.332}$ & .1063 & 25 & $4-3$ \\
\hline$Q_{25}$ & $=$ & $13.7 A^{0.856}$ & $S T^{-0.290}$ & $S^{0.342}$ & $S P^{-0.246}$ & $S N^{0.299}$ & .0995 & 23 & $4-4$ \\
\hline$Q_{50}$ & $=$ & $16.6 A^{0.857}$ & $S T^{-0.293}$ & $S^{0.357}$ & $S P^{-0.238}$ & $S N^{0.281}$ & .0964 & 22 & $4-5$ \\
\hline$Q_{100}$ & $=$ & $19.4 A^{0.857}$ & $S T^{-0.296}$ & $S^{0.371}$ & $S P^{-0.229}$ & $S N^{0.269}$ & .0954 & 22 & $4-6$ \\
\hline \multicolumn{10}{|c|}{ Area 5 (28 stations) } \\
\hline$Q_{2}$ & $=$ & $9.58 A^{0.981}$ & $S T^{-0.293}$ & $S^{0.416}$ & & & .1179 & 27 & $5-1$ \\
\hline$Q_{5}$ & $=$ & $15.1 A^{0.912}$ & $S T^{-0.358}$ & $S^{0.438}$ & & & .1127 & 26 & $5-2$ \\
\hline$Q_{10}$ & $=$ & $18.9 A^{0.913}$ & $S T^{-0.385}$ & $S^{0.447}$ & & & .1196 & 28 & $5-3$ \\
\hline$Q_{25}$ & $=$ & $23.6 A^{0.915}$ & $S T^{-0.408}$ & $S^{0.457}$ & & & .1349 & 32 & $5-4$ \\
\hline$Q_{50}$ & $=$ & $27.0 A^{0.916}$ & $S T^{-0.420}$ & $S^{0.463}$ & & & .1490 & 35 & $5-5$ \\
\hline$Q_{100}$ & $=$ & $30.6 A^{0.916}$ & $S T^{-0.430}$ & $S^{0.467}$ & & & .1637 & 39 & $5-6$ \\
\hline
\end{tabular}


Example 1: Determine the 100-year flood discharge for the Jump River at Sheldon (station number 05362000).

1. Locate the data in Appendix table A-1 by station number (05362000).

2. The 100-year flood discharge for Jump River is $Q_{100}=25,000 \mathrm{ft}^{3} / \mathrm{s}$.

The flood- frequency estimates presented in this report were based on the common logarithms of discharge. Therefore the weighting should be done with the logarithms of the flood-frequency estimates, and the best estimate is the antilogarithm of the weighted average. The flood-frequency estimates in Appendix tables A-1 and A-2 are essentially independent and, therefore, could be combined by this procedure to get an improved estimate at each site.

The appropriate equation (Interagency Committee Advisory Committee on Water Data, 1982) is

$$
z=\frac{x V_{y}+y V_{x}}{V_{x}+V_{y}}
$$

where

$$
\begin{aligned}
x \text { and } y & \begin{array}{l}
\text { are two independent estimates of a } \\
\text { flood-frequency characteristic, }
\end{array} \\
V_{\mathrm{x}} \text { and } V_{\mathrm{y}} & \begin{array}{l}
\text { are their respective variances, and } \\
z \quad \\
\text { is the weighted estimate of the flood- } \\
\text { frequency characteristic. }
\end{array}
\end{aligned}
$$

In the example of the Jump River at Sheldon,

$$
\begin{aligned}
& x=\log (25,000)=4.398 \text { from table A-1 } \\
& V_{\mathrm{x}}=(0.0435)^{2} \quad=0.00189 \text { from table A-1 } \\
& y=\log (41,100)=4.614 \text { from table A-2 } \\
& V_{\mathrm{y}}=(0.1153)^{2}=0.0133 \text { from table } 2 \text {, eq. } 2-6 \text {. } \\
& \log \left(\mathrm{Q}_{100}\right)=\frac{(4.398)(0.0133)+(4.614)(0.00189)}{0.0133+0.00189} \\
& \log \left(Q_{100}\right)=\frac{0.0585+0.00872}{0.0152}=4.422 \\
& \mathrm{Q}_{100}=26,400 \mathrm{ft}^{3} / \mathrm{s}
\end{aligned}
$$

\begin{tabular}{|c|c|c|c|}
\hline Basin characteristic & Minimum & Median & Maximum \\
\hline \multicolumn{4}{|c|}{ Area 1 (39 stations) } \\
\hline Drainage area $\left(\mathrm{mi}^{2}\right)$ & 0.28 & 25.0 & 2,120 \\
\hline $\begin{array}{l}\text { Main-channel slope } \\
(\mathrm{ft} / \mathrm{mi})\end{array}$ & 2.27 & 27.3 & 270 \\
\hline Forested area (percent) & .00 & 26.6 & 56.9 \\
\hline $\begin{array}{l}\text { 25-year, 24-hour } \\
\text { precipitation (in.) }\end{array}$ & 5.18 & 5.28 & 5.29 \\
\hline \multicolumn{4}{|c|}{ Area 2 (36 stations) } \\
\hline Drainage area $\left(\mathrm{mi}^{2}\right)$ & .56 & 27.4 & 1,760 \\
\hline $\begin{array}{l}\text { Soil permeability } \\
\quad(\mathrm{in} / \mathrm{hr})\end{array}$ & .20 & .91 & 2.88 \\
\hline $\begin{array}{l}\text { Main-channel slope } \\
(\mathrm{ft} / \mathrm{mi})\end{array}$ & 3.65 & 15.56 & 96 \\
\hline \multicolumn{4}{|c|}{ Area 3 (57 stations) } \\
\hline Drainage area $\left(\mathrm{mi}^{2}\right)$ & 1.00 & 22 & 2,240 \\
\hline $\begin{array}{l}\text { Soil permeability } \\
\quad \text { (in } / \mathrm{hr})\end{array}$ & .12 & 1.81 & 8.46 \\
\hline Storage (percent) & .00 & 15.5 & 39.7 \\
\hline $\begin{array}{l}\text { 25-year, 24-hour } \\
\text { precipitation (in.) }\end{array}$ & 4.24 & 4.38 & 5.29 \\
\hline \multicolumn{4}{|c|}{ Area 4 (40 stations) } \\
\hline Drainage area $\left(\mathrm{mi}^{2}\right)$ & .66 & 35.0 & 696 \\
\hline Storage (percent) & .00 & 9.40 & 52.4 \\
\hline $\begin{array}{l}\text { Main-channel slope } \\
(\mathrm{ft} / \mathrm{mi})\end{array}$ & 1.08 & 11.6 & 204 \\
\hline $\begin{array}{l}\text { Soil permeability } \\
\quad(\mathrm{in} / \mathrm{hr})\end{array}$ & .12 & .82 & 4.68 \\
\hline $\begin{array}{l}\text { Mean annual snowfall } \\
\text { (in.) }\end{array}$ & 34.4 & 48.3 & 172 \\
\hline \multicolumn{4}{|c|}{ Area 5 (28 stations) } \\
\hline Drainage area $\left(\mathrm{mi}^{2}\right)$ & 1.32 & 18.9 & 3,340 \\
\hline Storage (percent) & .00 & 1.65 & 15.4 \\
\hline $\begin{array}{l}\text { Main-channel slope } \\
(\mathrm{ft} / \mathrm{mi})\end{array}$ & .74 & 12.85 & 74.2 \\
\hline
\end{tabular}

Table 3. Ranges of basin characteristics used in regression analysis

$\left[\mathrm{mi}^{2}\right.$, square miles; ft/mi, feet per mile; in., inches; in/hr, inches per hour. Flood-frequency areas are shown in figure 3.] 


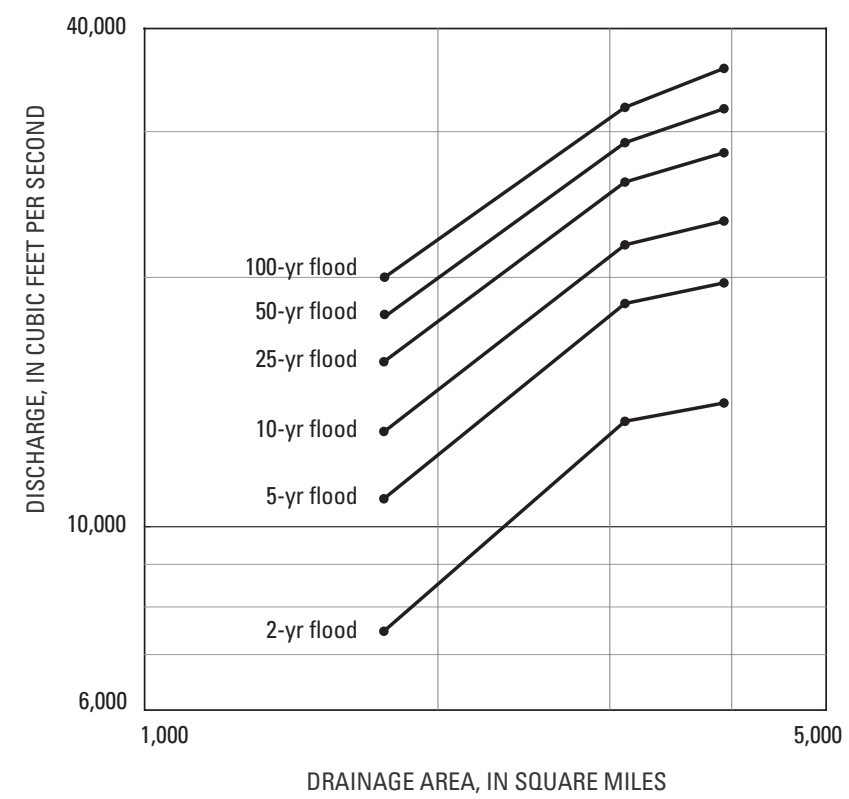

Figure 4. Relation of discharge to drainage area for selected flood frequencies along the main stem of the Menominee River, Wisconsin and Michigan.

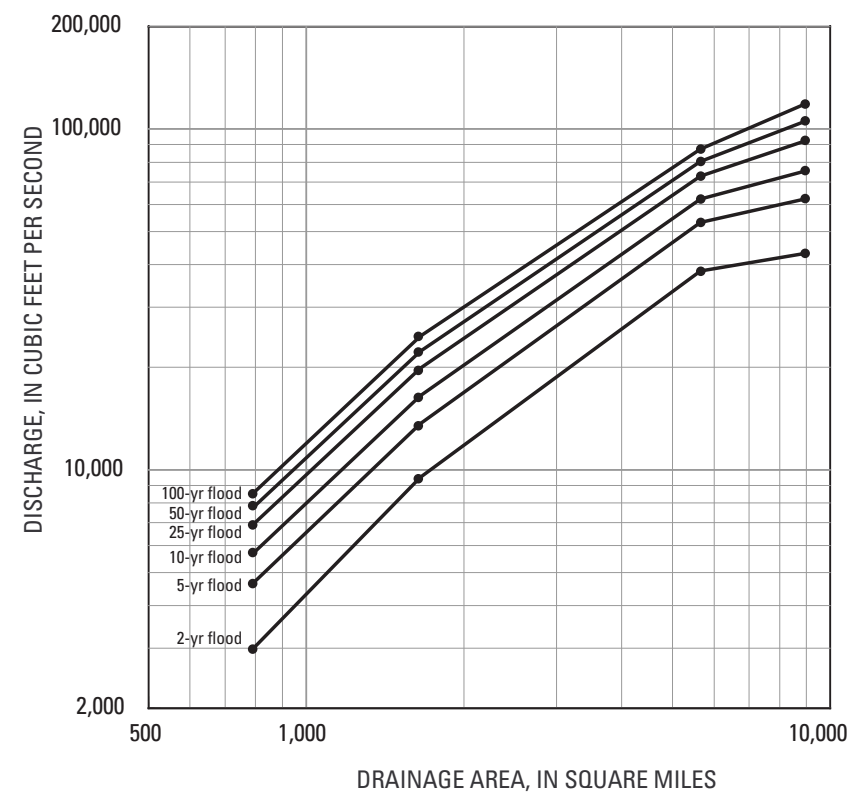

Figure 6. Relation of discharge to drainage area for selected flood frequencies along the main stem of the Chippewa River, Wisconsin.

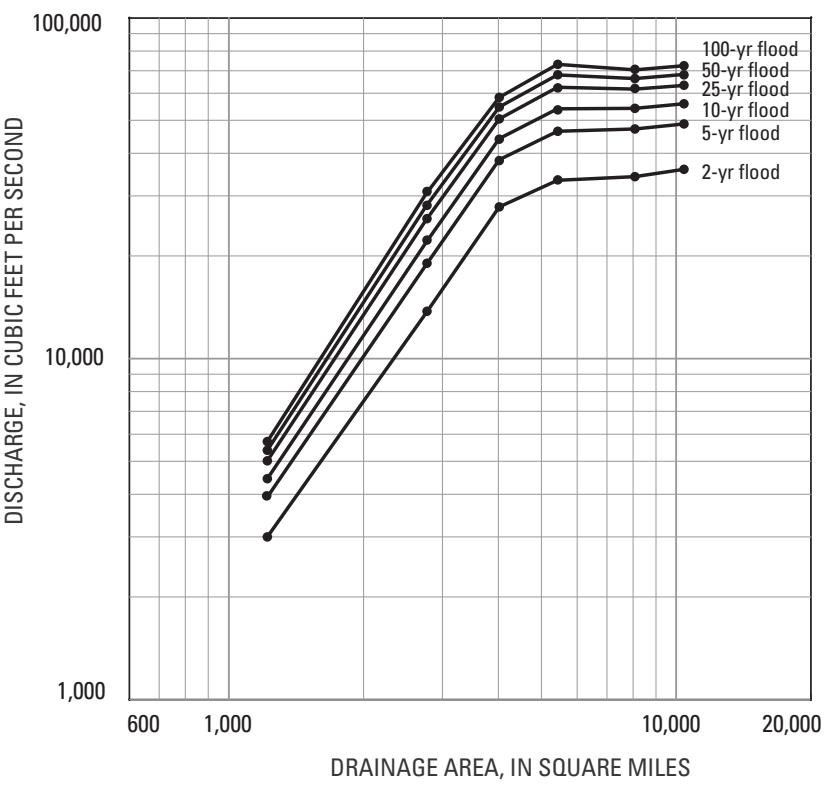

Figure 5. Relation of discharge to drainage area for selected flood frequencies along the main stem of the Wisconsin River, Wisconsin.

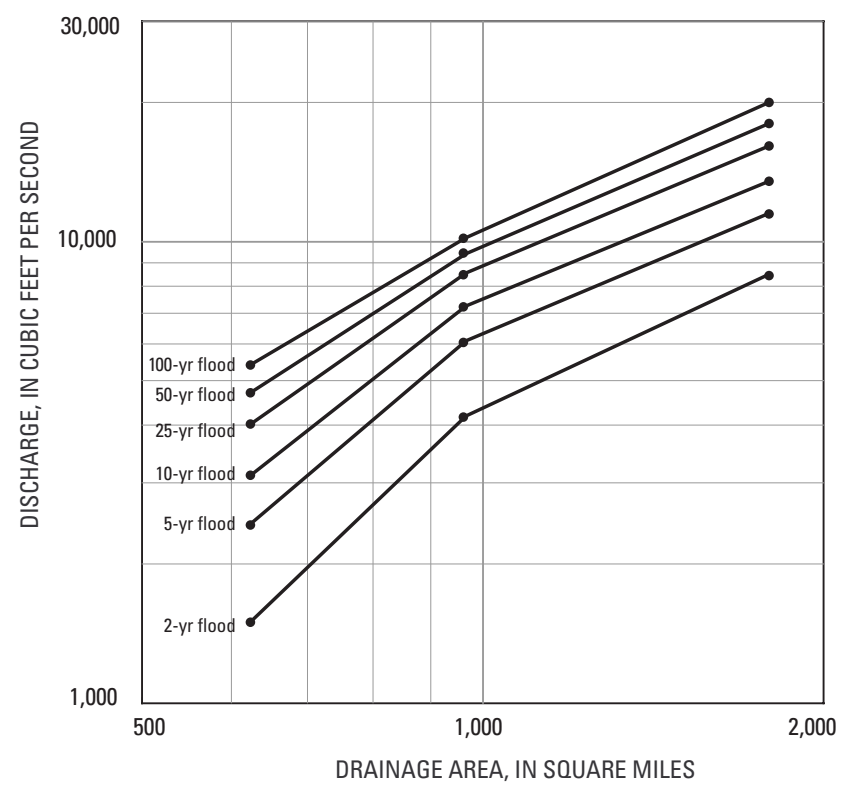

Figure 7. Relation of discharge to drainage area for selected flood frequencies along the main stem of the Flambeau River, Wisconsin. 


\section{Sites on Streams near Streamflow-Gaging Stations}

Flood-frequency characteristics at sites near a streamflow-gaging station on the same stream are determined using a combination of the station's flood frequency characteristics and the characteristics determined by the regression equations. The procedure is applicable for sites that have a drainage area between 50 and 150 percent of the drainage area of the station. The suitability of the flood-frequency characteristics should be determined by comparing them with flood-frequency characteristics at the station. The following procedure was used by Curtis (1987) for streams in Illinois based on work by Sauer (1974). The procedure is as follows:

First, the ratio $r^{\prime}$ is defined by

$$
r^{\prime}=\frac{Q_{g}}{\hat{Q}_{g}}-\left(\frac{\left|A_{g}-A_{u}\right|}{0.5 A_{g}}\right)\left(\frac{Q_{g}}{\hat{Q}_{g}}-1\right)
$$

where

$$
\begin{array}{ll}
r^{\prime} & \text { is the adjustment ratio, } \\
Q_{g} & \begin{array}{l}
\text { is a flood-frequency characteristic } \\
\text { determined at the station, }
\end{array} \\
\hat{Q}_{g} \quad \begin{array}{l}
\text { is a flood-frequency characteristic } \\
\text { determined for the station by the } \\
\text { appropriate multiple-regression }
\end{array} \\
\quad \text { equation (table 2), } \\
A_{g} \quad \text { is drainage area of the gaged site, and } \\
A_{u} \quad \text { is drainage area of the ungaged site. }
\end{array}
$$

The adjusted flood-frequency characteristic for the ungaged site $\left(Q_{u}\right)$ is computed by the equation

$$
Q_{u}=r^{\prime} \hat{Q}_{u}
$$

where

$$
\begin{aligned}
& \hat{Q}_{u} \quad \text { is a flood-frequency characteristic } \\
& \text { determined for the ungaged site by the } \\
& \text { appropriate multiple-regression equation. }
\end{aligned}
$$

If the difference in drainage area between the ungaged site and the gaged site is more than 50 percent, equations 7 and 8 should not be used. In this case, the appropriate multiple-regression equation from table 2 should be used without adjustment but should be compared to the flood-frequency characteristic of the station on the stream for suitability. If the drainage area crosses the boundary of two flood-frequency areas, compute the flood frequency using equations from both areas. Compute the final flood-frequency estimates as the weighted average of the two estimates weighted by the proportion of drainage area in each of the flood-frequency areas.

Example 2: Determine the 100-year flood of Black Earth Creek at U.S. Highway 14, which is 2 miles downstream from the station Black Earth Creek at Black Earth (05406500).

First, equation 1-6 from table 2 is used to determine the 100-year flood estimate at the gaged site:

$$
Q_{100}=44.2 A^{0.893} S^{0.571} F^{-0.312} I_{25}^{7.56}
$$

The drainage-basin characteristics at the gaged site are given in Appendix table A-2:

$A$ (contributing drainage area) $=42.8 \mathrm{mi}^{2}$,

$\mathrm{S}$ (main channel slope) $=9.42 \mathrm{ft} / \mathrm{mi}$,

FOR (forest cover in percent of basin area plus 1$)=21.8+1=22.8$, and

$I_{25}$ (25-year, 24-hour precipitation index $)=5.18-4.2=0.98$ inches.

Substituting into equation 1-6,

$$
\begin{aligned}
\hat{Q}_{u} & =44.2(42.8)^{0.893}(9.42)^{0.571}(22.8)^{-0.312}(0.98)^{7.56} \\
& =1,470 \mathrm{ft}^{3} / \mathrm{s}
\end{aligned}
$$

$\hat{Q}_{u}$ at the Black Earth Creek at U.S. Highway 14 can be determined at the ungaged site by use of the same eq. 1-6 and the procedure that was used to determine $\hat{Q}_{g}$ at the station, as follows:

$$
Q_{100}=44.2 A^{0.893} S^{0.571} F^{-0.312} I_{25}^{7.56} \quad(1-6, \text { table 2) }
$$

The drainage-basin characteristics at this site were determined to be:

$$
\begin{aligned}
A & =45.0 \mathrm{mi}^{2}\left(2.8 \mathrm{mi}^{2} \text { non-contributing area }\right) \\
\mathrm{S} & =8.81 \mathrm{ft} / \mathrm{mi}, \\
\text { FOR } & =21.9+1=22.9, \text { and } \\
I_{25} & =5.18-4.2=0.98 .
\end{aligned}
$$

Substituting into equation 1-6,

$$
\begin{aligned}
\hat{Q}_{u} & =44.2(45.0)^{0.893}(8.81)^{0.571}(22.9)^{-0.312}(0.98)^{7.56} \\
& =1,480 \mathrm{ft}^{3} / \mathrm{s}
\end{aligned}
$$


From Appendix table A-2, the 100-year flood at the gaging station $\left(Q_{g}\right)$ is $1,650 \mathrm{ft}^{3} / \mathrm{s}$. Next, Equation 7 is used to determine the adjustment factor $\left(r^{\prime}\right)$ :

$$
\begin{aligned}
& r^{\prime}=\frac{Q_{g}}{\hat{Q}_{g}}-\left(\frac{\left|A_{g}-A_{u}\right|}{0.5 A_{g}}\right)\left(\frac{Q_{g}}{\hat{Q}_{g}}-1\right) \\
& r^{\prime}=\frac{1,650}{1,470}-\left(\frac{|42.8-47.8|}{0.5 \cdot 42.8}\right)\left(\frac{1,650}{1,470}-1\right)=1.094
\end{aligned}
$$

Finally, Equation 8 is used to compute the adjusted discharge at the ungaged site, thus

$$
Q_{u}=r^{\prime} \hat{Q}_{u}=1.094 \cdot 1,480=1,620 \mathrm{ft}^{3} / \mathrm{s}
$$

If the drainage area crosses the boundary of two flood-frequency areas, compute the flood frequency using equations from both areas. Compute the final flood-frequency estimates as the weighted average of the two estimates weighted by the proportion of drainage area in each of the flood-frequency areas.

\section{Sites on Streams Without Streamflow-Gaging Stations}

Flood-frequency characteristics at sites on ungaged streams are calculated using equations 1-1 through 5-6 from table 2 .

Example 3: Determine the 100-year discharge for Tappen Coulee at Blair. This site is in area 1 ; therefore, use equation 1-6 from table 2:

$$
Q_{100}=44.2 A^{0.893} S^{0.571} \mathrm{FOR}^{-0.312} I_{25}^{7.56}
$$

1. The drainage area $A$ was determined to be $4.48 \mathrm{mi}^{2}$ from Henrich and Daniel (1983).

2. The main channel slope $(S)$ was computed from U.S. Geological Survey topographic maps as follows:

(a) The river or coulee length was measured from the site to the basin divide. For forked streams, the fork with the larger drainage area is followed.

(b) The elevations at points that are 10 and 85 percent of the total stream length from the site are then determined.

(c) Next, the difference in elevation between the sites is determined and is divided by the distance, in miles, between the points. By use of the appropriate quadrangle maps (Blair, 1968, 1:24,000; Hegg, 1969,
$1: 24,000)$, the total length of the stream for this site was determined to be $5.20 \mathrm{mi}$. The elevation at the 10 -percent point is $847.6 \mathrm{ft}$ and at the 85 -percent point is $963.0 \mathrm{ft}$. The main channel slope is

$$
\mathrm{S}=\frac{963.0-847.6}{5.20}=29.6 \mathrm{ft} / \mathrm{mi}
$$

3. The percent forest cover was determined to be 45.8 percent based on land use/land coverage in the WISCLAN database (Reese and others, 2002) and a digitized drainage-basin outline after Henrich and Daniel (1983).

4. The precipitation intensity index $\left(I_{25}\right)$ was determined by locating the site in figure 1 and determining the 25-year, 24-hour precipitation intensity, then subtracting 4.2. The 25-year precipitation intensity for climatic section 4 is 5.28; therefore $I_{25}$ is 1.08 .

5. Substituting these values into equation 1-6:

$$
\begin{aligned}
Q_{100} & =44.2(4.48)^{0.893}(29.6)^{0.571}(46.8)^{-0.312}(1.08)^{7.56} \\
& =629
\end{aligned}
$$

If the drainage area crosses the boundary of two flood-frequency areas, compute the flood frequency using equations from both areas. Compute the final flood-frequency estimates as the weighted average of the two estimates weighted by the proportion of drainage area in each of the flood-frequency areas.

\section{Sites on Regulated Streams}

Flood-frequency characteristics at ungaged sites on regulated streams are estimated using the flood-frequency characteristics at streamflow-gaging stations on the regulated streams and adjusting the characteristics according to the relation of drainage area and discharge. Graphs showing the peak discharge of floods plotted at selected recurrence intervals against drainage area are presented in figures 4-7 for the following major regulated streams in Wisconsin:

a. Menominee River between Wisconsin and Michigan (fig. 4),

b. Wisconsin River from the mouth to Rainbow Reservoir near Lake Tomahawk (fig. 5),

c. Chippewa River from the mouth to Lake Chippewa in Sawyer County (fig. 6), and 
d. Flambeau River from its mouth to Flambeau Flowage northeast of Park Falls (fig. 7).

Storage reservoirs in these basins can significantly change the flood-frequency characteristics at streamflowgaging stations. Flood-frequency analyses were performed for stations along the main stems for the period of record beginning with the completion of the last large storage reservoir in each basin for the Menominee, Chippewa, and Flambeau Rivers. These analyses represent flood-frequency characteristics in 2000. Completion dates for the last large storage reservoir for each basin follow: 1941 for the Menominee River; 1926 for the Flambeau River; and 1923 for the Chippewa River. For the Wisconsin River, flood peaks prior to 1976 were simulated using a model of the river system (Krug and House, 1980). Observed flood peaks were used after 1976.

\section{Summary and Conclusions}

Equations, tables, and graphs presented in this report provide a means for estimating flood-frequency characteristics for rural streams in Wisconsin. Flood-frequency characteristics were determined at 104 crest-stage stations, at 33 discontinued crest-stage stations, at 108 continuous streamflow-gaging stations, and at 67 discontinued streamflow-gaging stations using the log-Pearson Type III frequency distribution. The flood-frequency characteristics at 96 crest-gage stations, 29 discontinued crest-gage stations, 48 streamflow-gaging stations, and 27 discontinued streamflow-gaging stations, and their drainage-basin characteristics, were used in a multiple-regression analysis to derive equations for estimating flood-frequency characteristics. The generalized least-square procedure was used in the multiple-regression analyses. The state was divided into five areas with similar physiographic characteristics.

For the 100-year flood discharge, the standard errors of prediction in three of the five areas were relatively unchanged from those reported in Krug and others (1992). The most notable discrepancies were in areas 1 and 5 (southwestern and south-central Wisconsin) where the standard error of estimate increased from 26 and 22 percent to 44 and 39 percent, respectively, for the 100-year floods. This discrepancy may be due to nonstationarity in the discharge record coupled with the use of relatively recent snowfall and precipitation data. The standard error of estimate for the 100-year flood equation ranged statewide from 22 percent for streams in the eastern area to 44 percent for streams in the southwestern area. Drain- age area, channel slope, soil permeability, storage, rainfall intensity, and forest cover are the most significant drainage-basin characteristics for estimating flood-frequency characteristics.

Graphical relations of flood-frequency characteristics and drainage area are presented for the regulated Menominee, Flambeau, Chippewa, and Wisconsin Rivers. The relations were developed by use of data at stations for periods after the last large storage reservoir was constructed in each basin. For the Wisconsin River, the source of simulated flood discharges through 1976 was a report by Krug and House (1980). Observed flood discharges were used after 1976.

\section{References Cited}

Conger, D.H., 1971, Estimating magnitude and frequency of floods in Wisconsin: Madison, Wis., U.S. Geological Survey Open-File Report, 200 p.

1981, Techniques for estimating magnitude and frequency of floods for Wisconsin streams: U.S. Geological Survey Open-File Report 82-1214, 115 p.

1986, Estimating magnitude and frequency of floods for Wisconsin urban streams: U.S. Geological Survey Water-Resources Investigations Report 86-4005, 18 p.

Curtis, G.W., 1987, Technique for estimating flood-peak discharges and frequencies on rural streams: U.S. Geological Survey Water-Resources Investigations Report 87-4207, $79 \mathrm{p}$.

Daly, C., Gibson, W., and Taylor, G., 2000, United States mean monthly and annual snowfall: Spatial Climate Analysis Service, Oregon State University.

Ericson, D.W., 1961, Floods in Wisconsin, magnitude and frequency: Madison, Wis., U.S. Geological Survey Open-File Report, 109 p.

Gebert, W.A., and Krug, W.R., 1996, Streamflow trends in Wisconsin's driftless area: Journal of the American Water Resources Association, v. 32, no. 4, p. 733-744.

Henrich, E.W., and Daniel, D.N., 1983, Drainage area data for Wisconsin streams: U.S. Geological Survey OpenFile Report 83-933, 322 p.

Hole, F.D., Beatty, M.T., Lee, G.B., and Klingelhoets, A.J., 1968, Soil map of Wisconsin: Wisconsin Geological and Natural History Survey, scale 1:250,000, 11 sheets.

Huff, F.A., and Angel, J.R., 1992, Rainfall frequency atlas of the midwest: Illinois State Water Survey Bulletin 71. 
Interagency Advisory Committee on Water Data, 1982, Guidelines for determining flood flow frequency:

Bulletin 17B of the Hydrology Subcommittee, U.S.

Geological Survey, Office of Water Data Coordination, Reston, Va.

Krug, W.R., Conger, D.H., and Gebert, W.A., 1992, Flood-frequency characteristics of Wisconsin streams: U.S. Geological Survey Water-Resources Investigations Report 91-4128, 185 p.

Krug, W.R., and House, L.B., 1980, Streamflow model of Wisconsin River for estimating flood frequency and volume: U.S. Geological Survey Water-Resources Investigations Open-File Report 80-1103, 44 p.

Patterson, J.L., and Gamble, C.R., 1968, Magnitude and frequency of floods in the United States, part 5, Hudson Bay and Upper Mississippi River basins: U.S. Geological Survey Water-Supply Paper 1678, 546 p.

Reese, H.M., Lillesand, T.M., Nagel, D.E., Stewart, J.S., Goldmann, R.A., Simmons, T.E., Chipman, J.W., and Tessar, P.A., 2002, Statewide land cover derived from multiseasonal Landsat TM data-A retrospective of the WISCLAND project: Remote Sensing of Environment, v. 82 , no. $2-3$, p. 224-237.

Sauer, V.B., 1974, Flood characteristics of Oklahoma streams: U.S. Geological Survey Water-Resources Investigations 52-73, $301 \mathrm{p}$.

Stedinger, J.R., and Tasker, G.D., 1985, Regional hydrologic analysis 1 - Ordinary, weighted and generalized least squares compared: Water Resources Research, v. 21 , no. 9 , p. 1421-1432.

Tasker, G.D., Eychaner, J.H., and Stedinger, J.R., 1986, Application of generalized least squares in regional hydrologic regression analysis, in Subitzky, Seymour, ed., Selected papers in the hydrologic sciences 1986: U.S. Geological Survey Water-Supply Paper 2310, p. $107-115$.

U.S. Department of Agriculture, Soil Conservation Service, 1964, Engineering test data and interpretations for major soils of Wisconsin: table 11, p. 3-43.

Wiitala, S.W., 1965, Magnitude and frequency of floods in the United States, part 4, St. Lawrence River basin: U.S. Geological Survey Water-Supply Paper 1677, 357 p. 


\section{Appendixes}




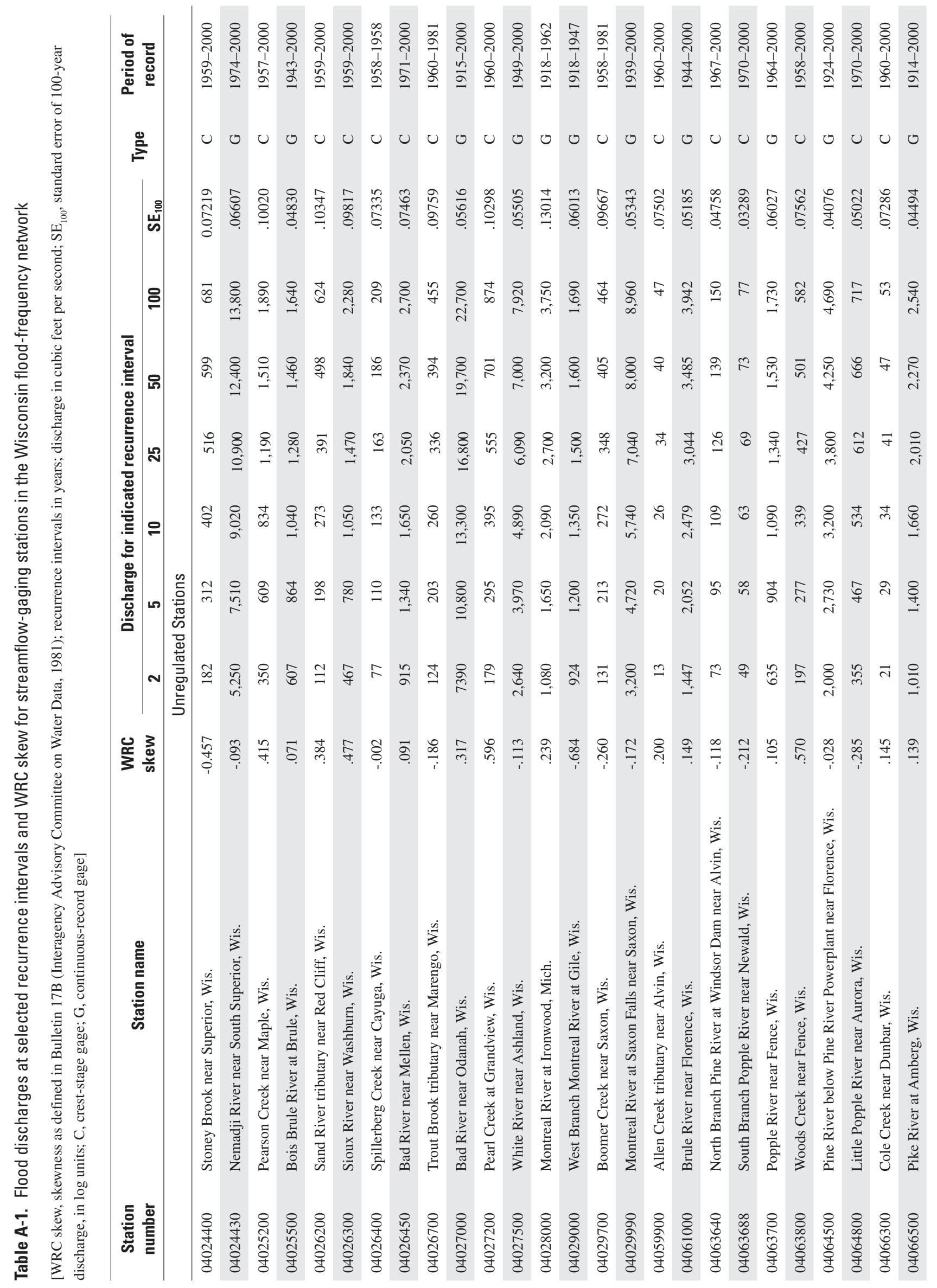




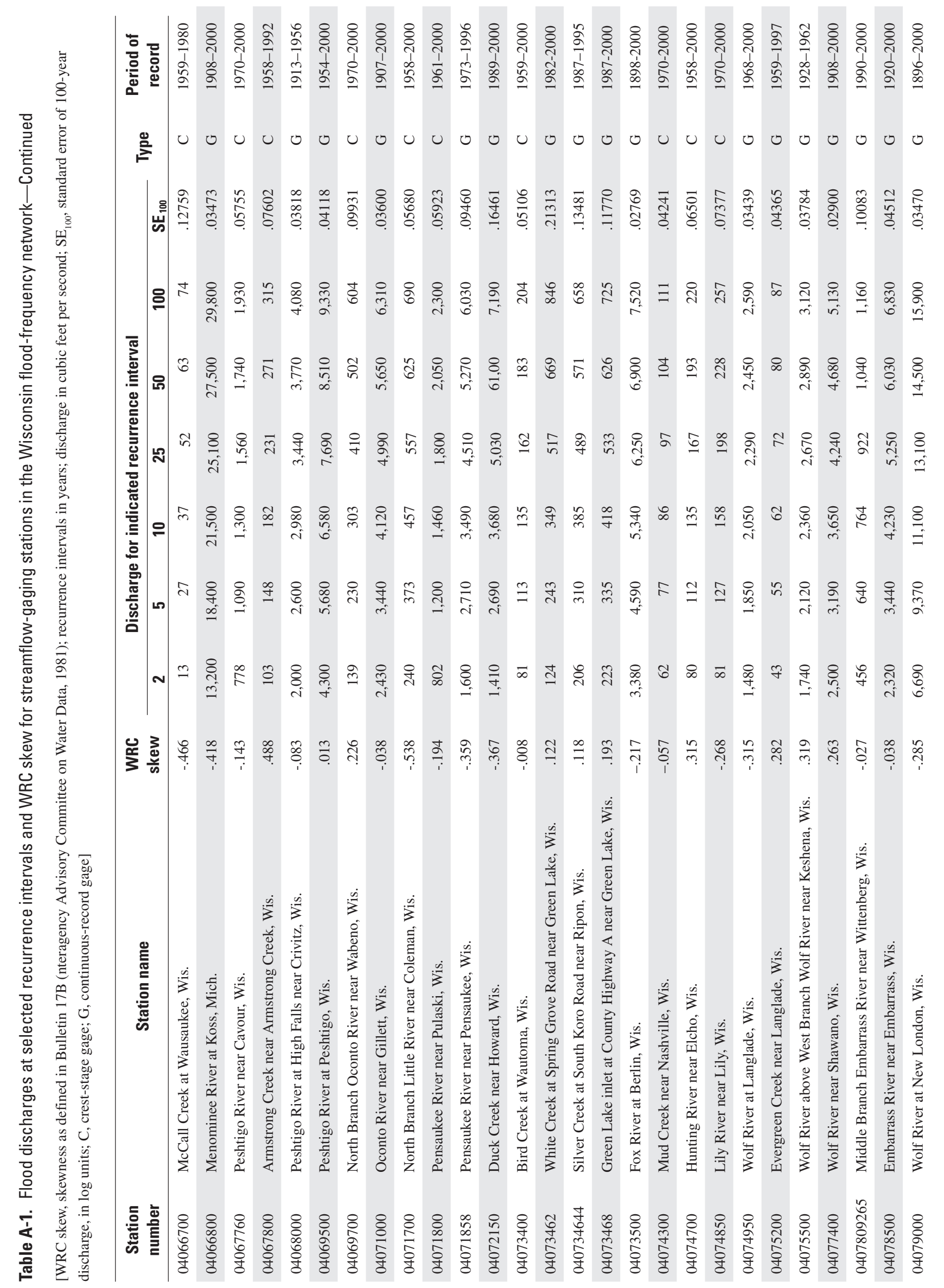




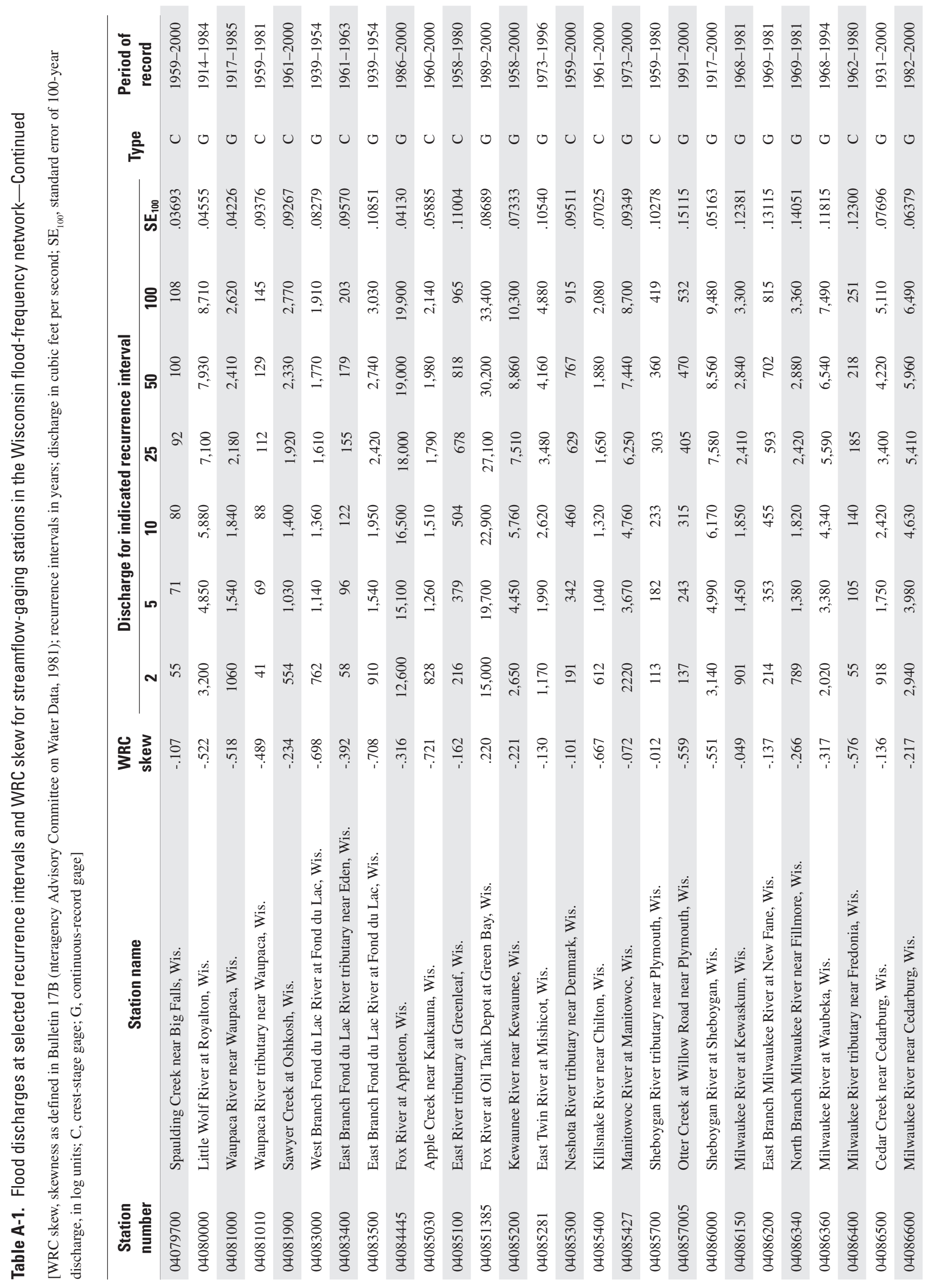


히 \& \&

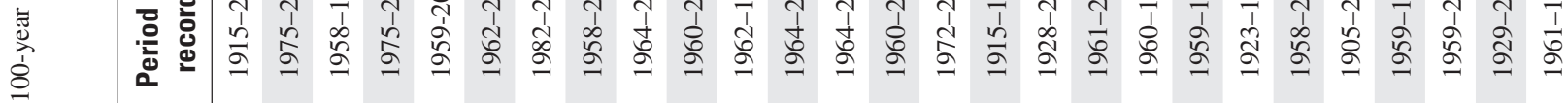




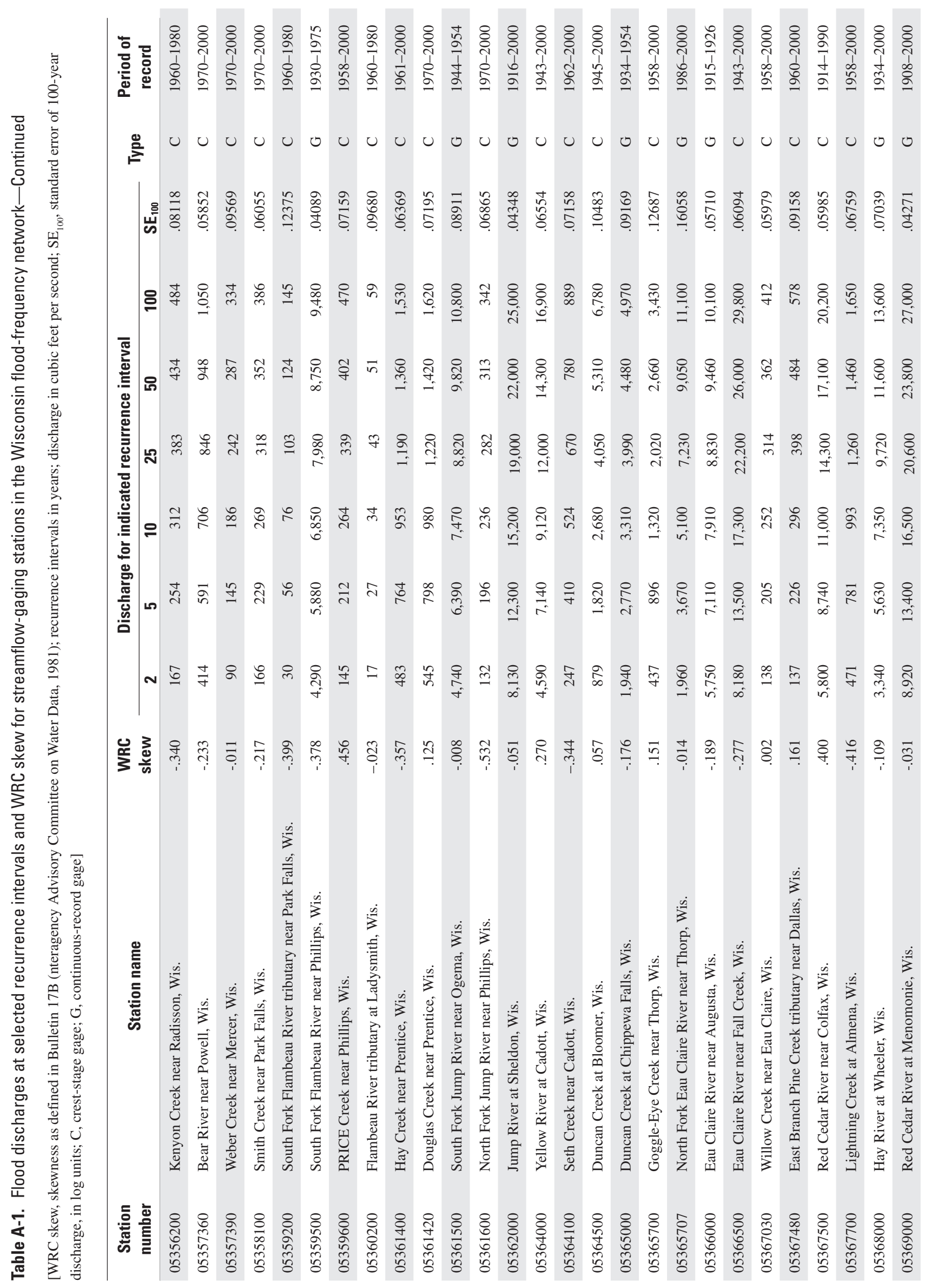




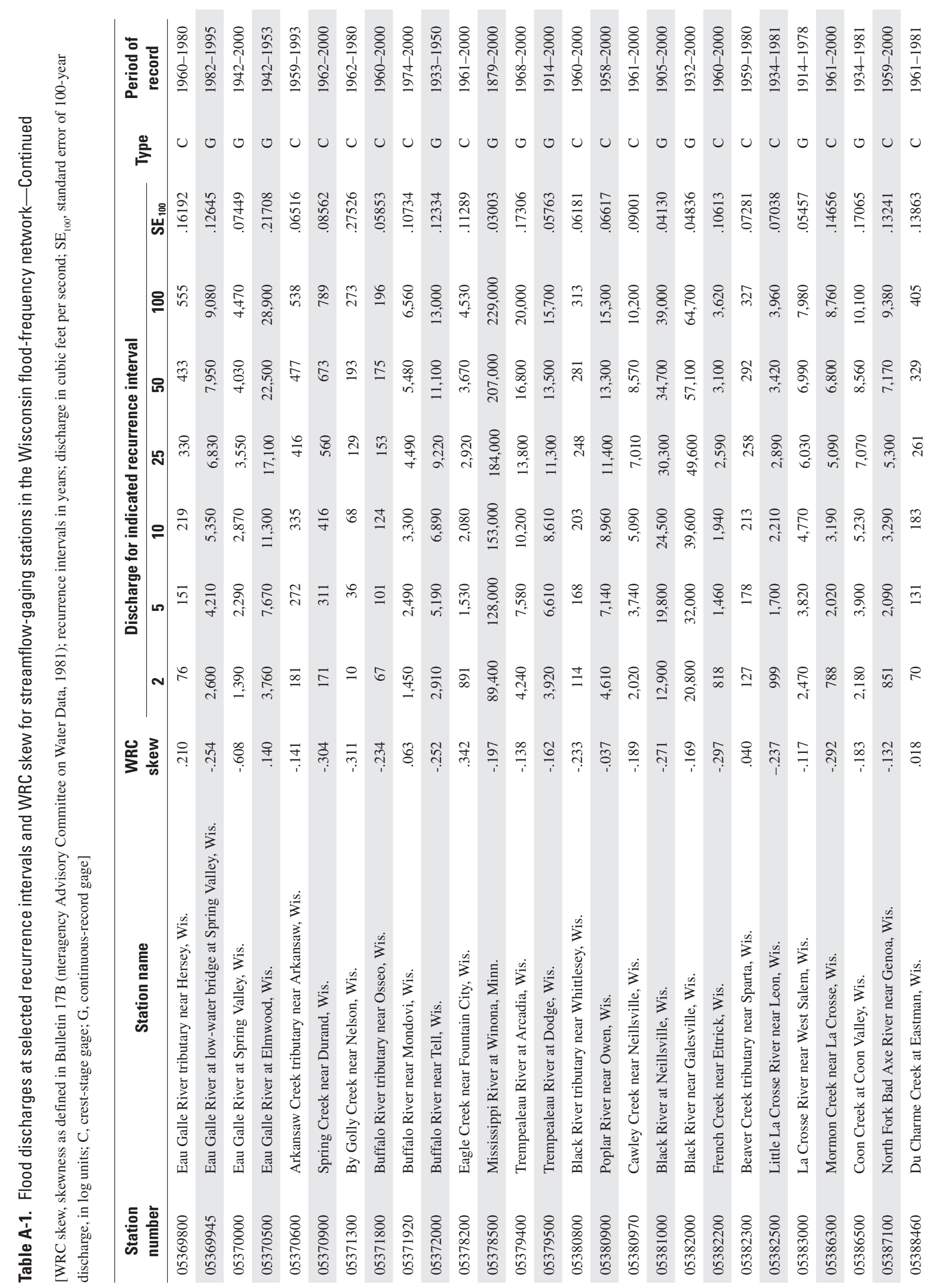




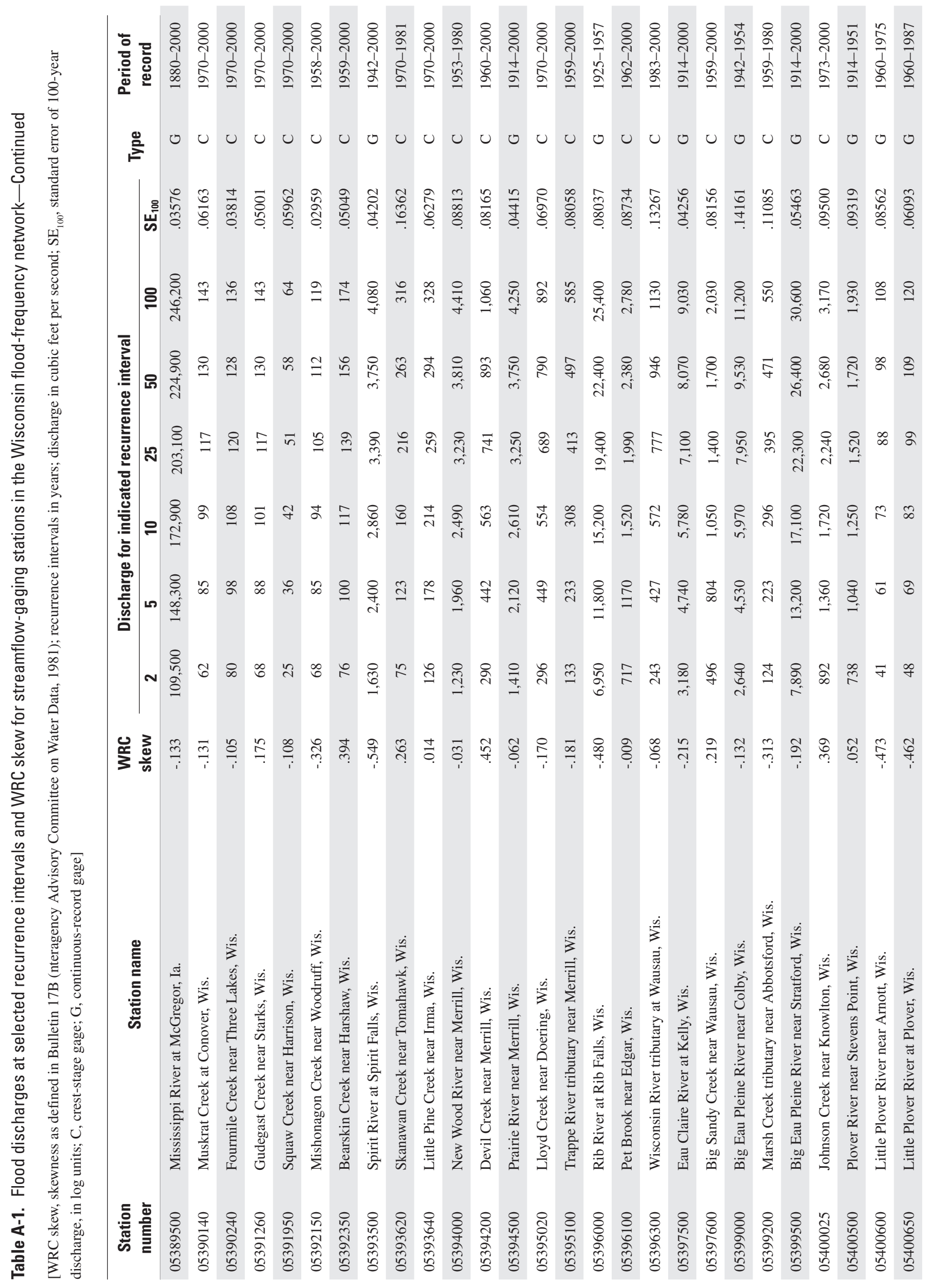




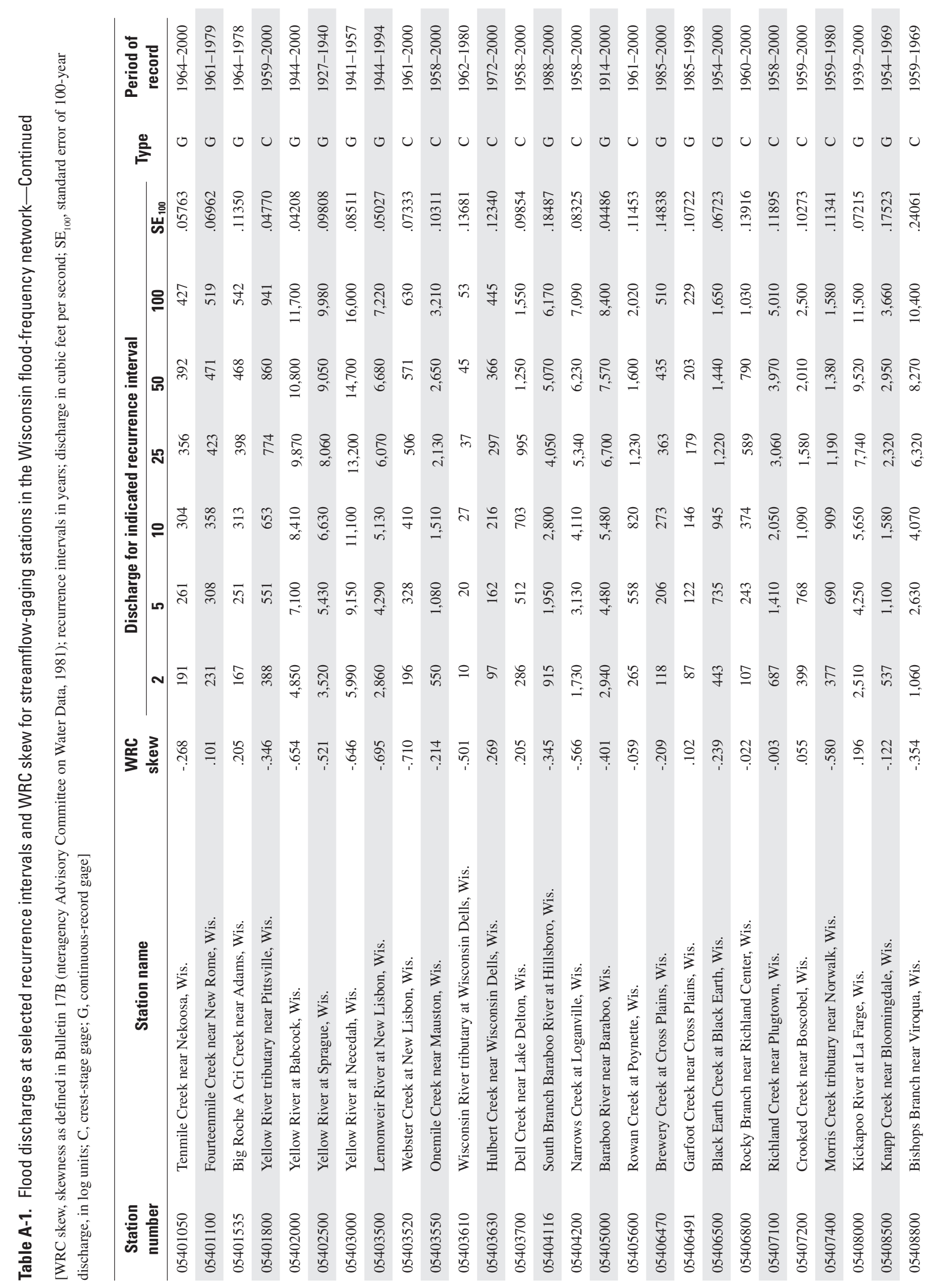




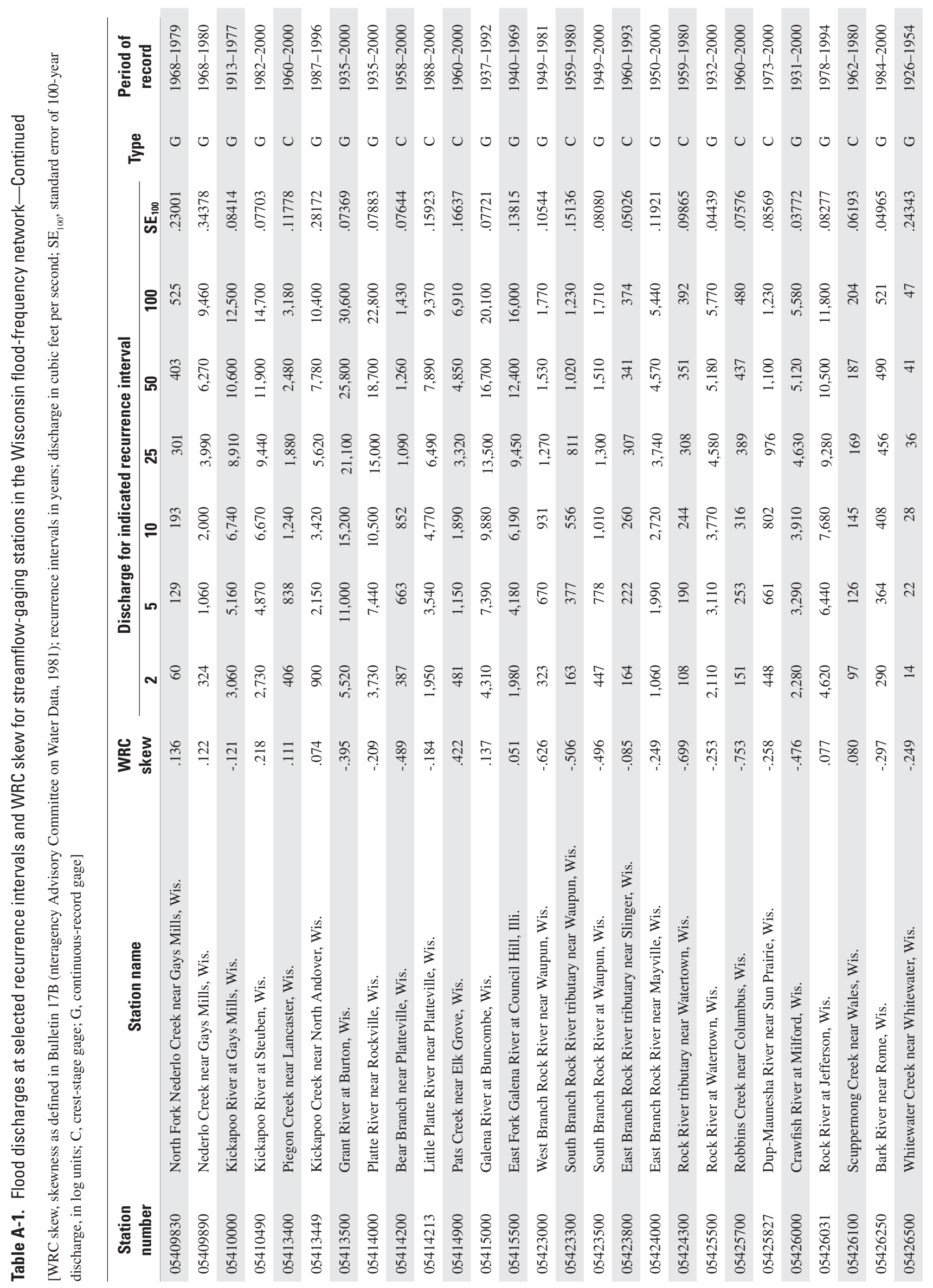




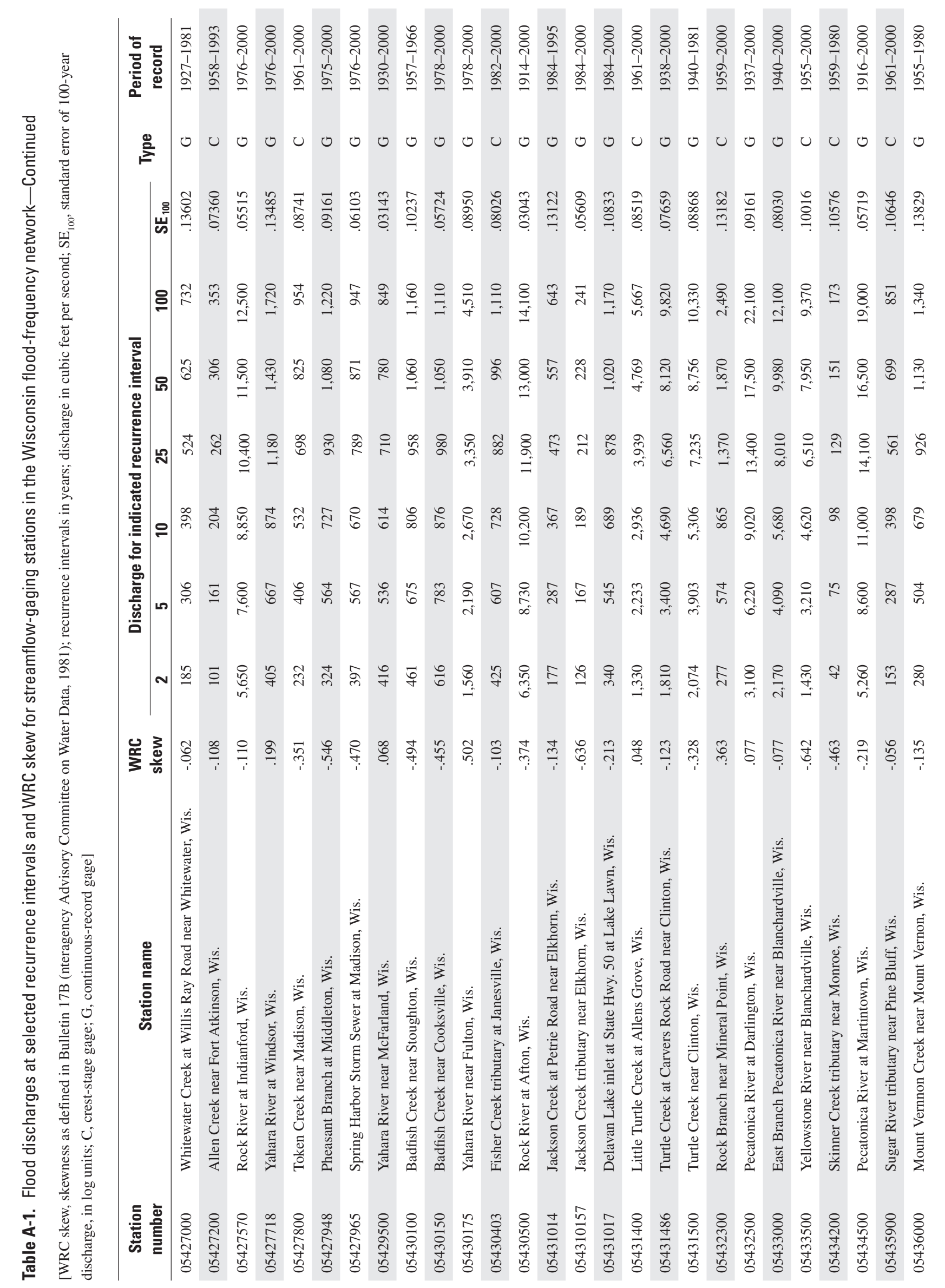




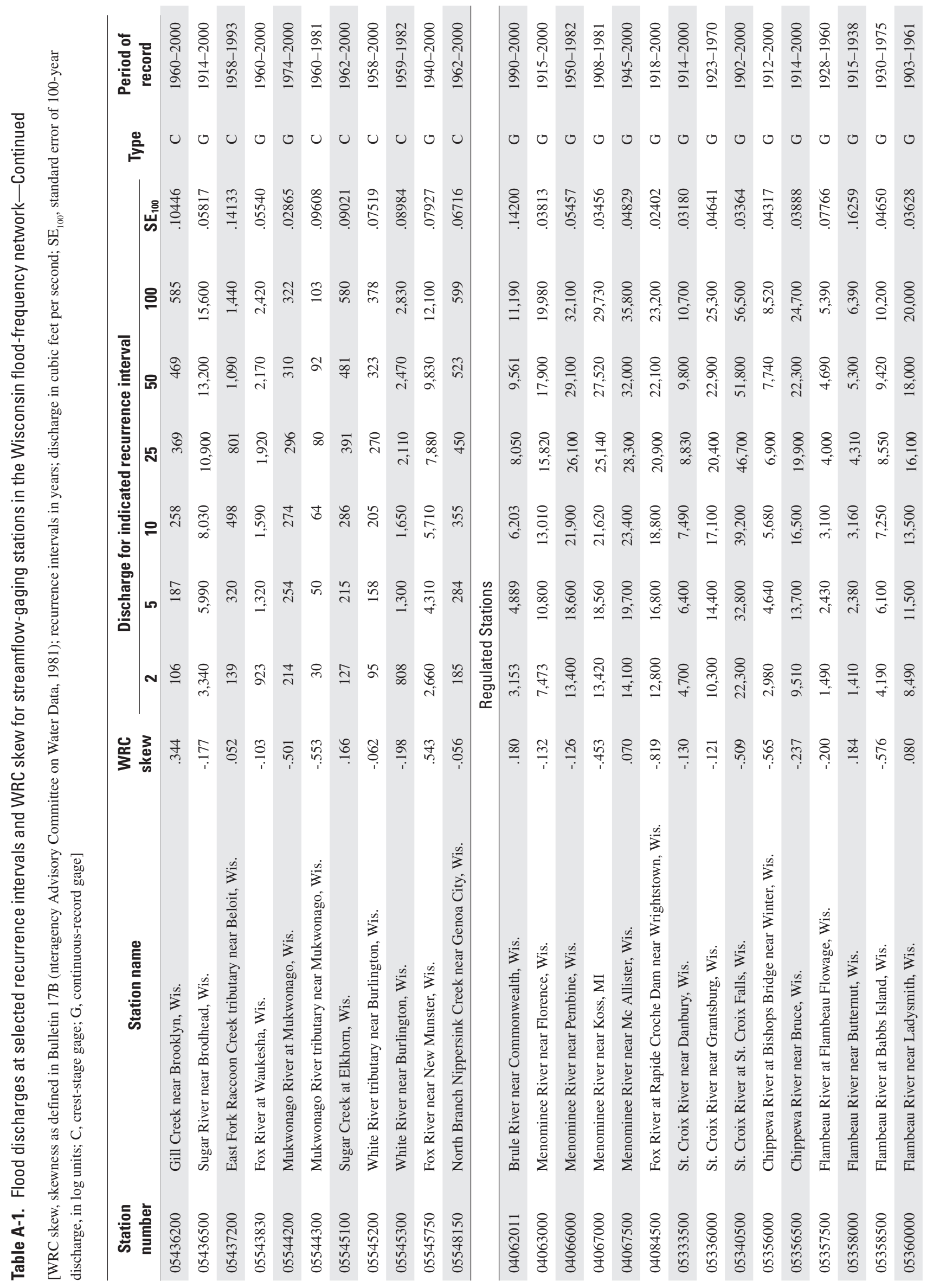




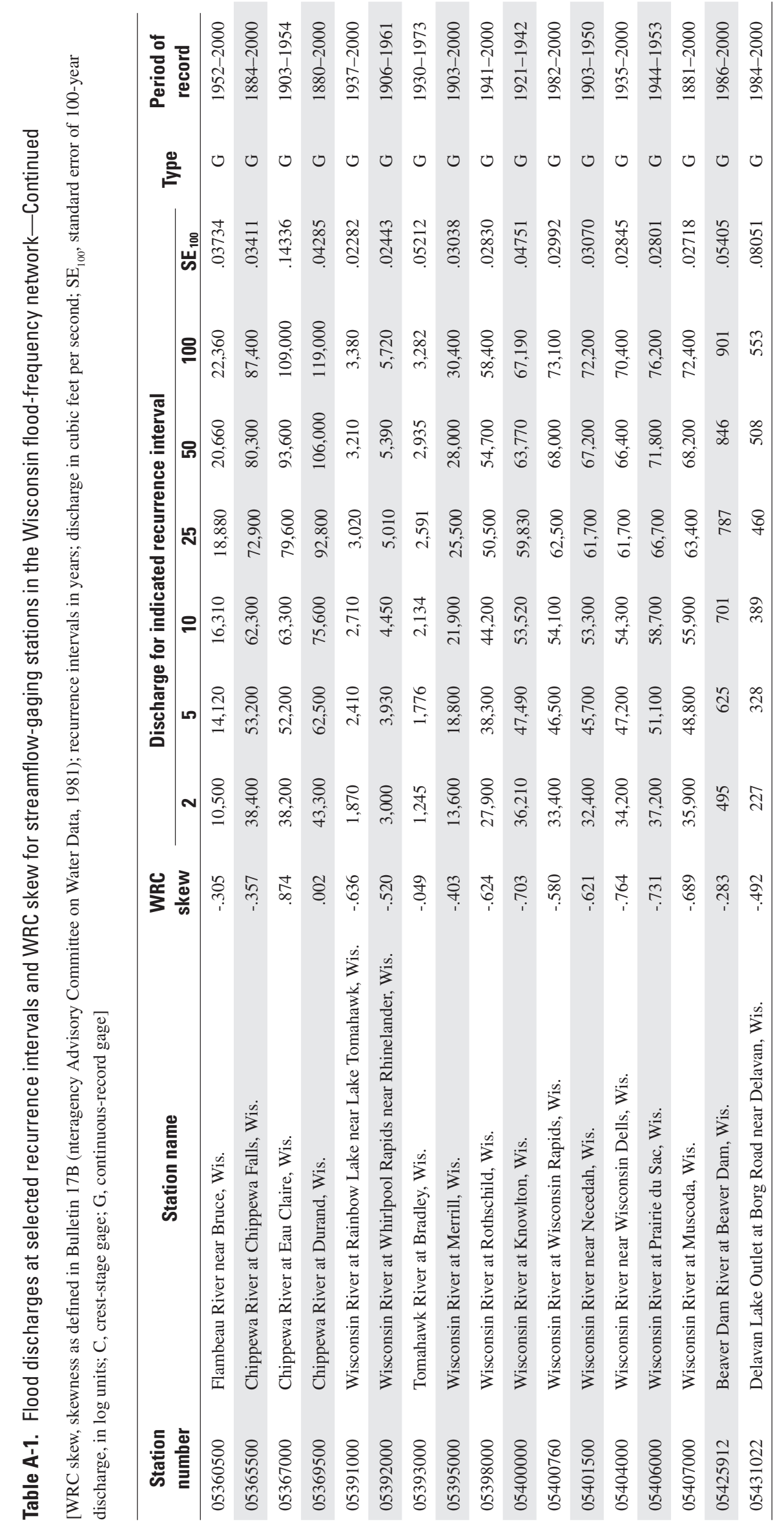




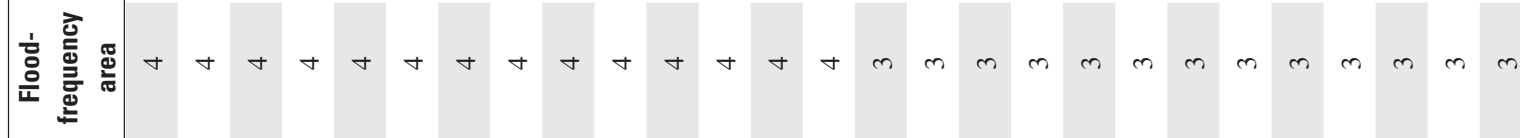

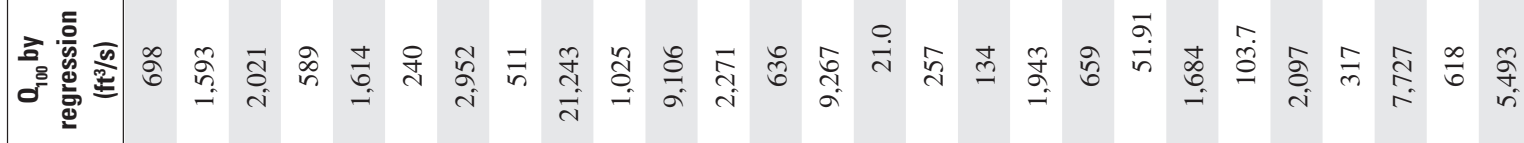

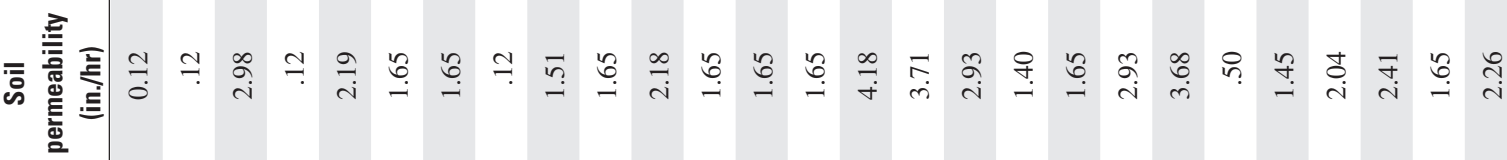

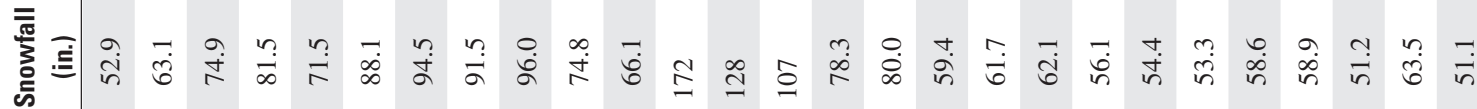

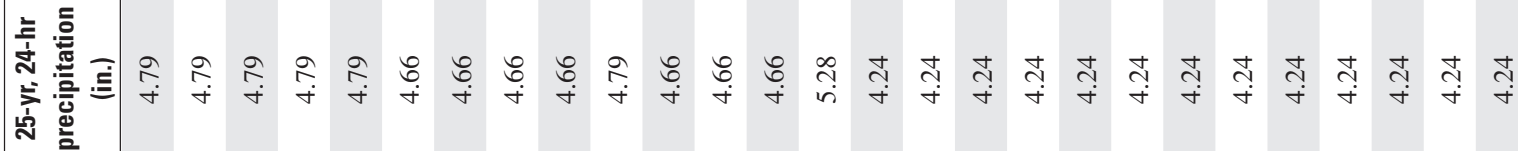

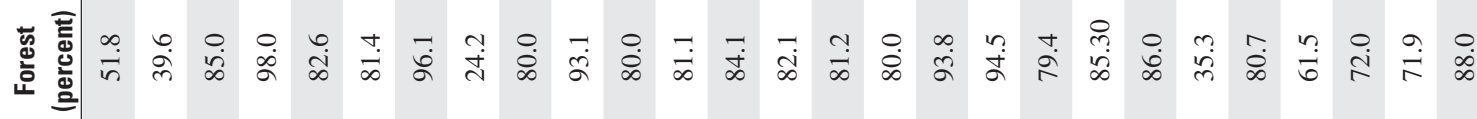

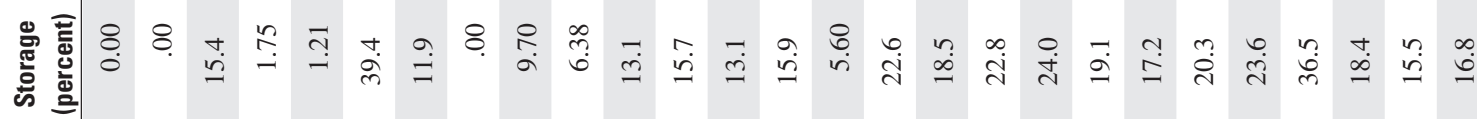

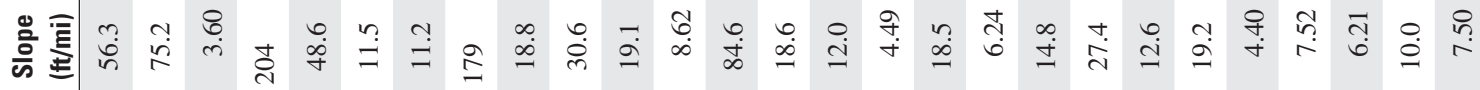

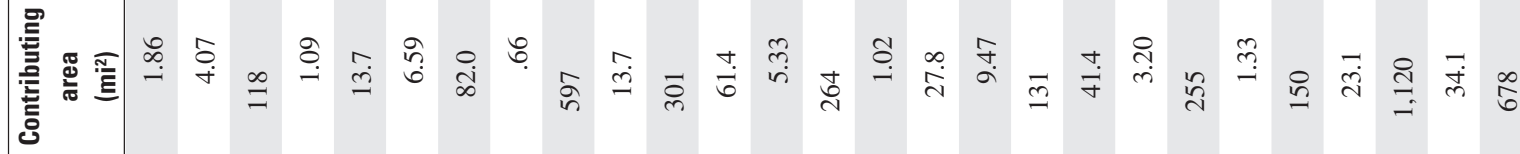

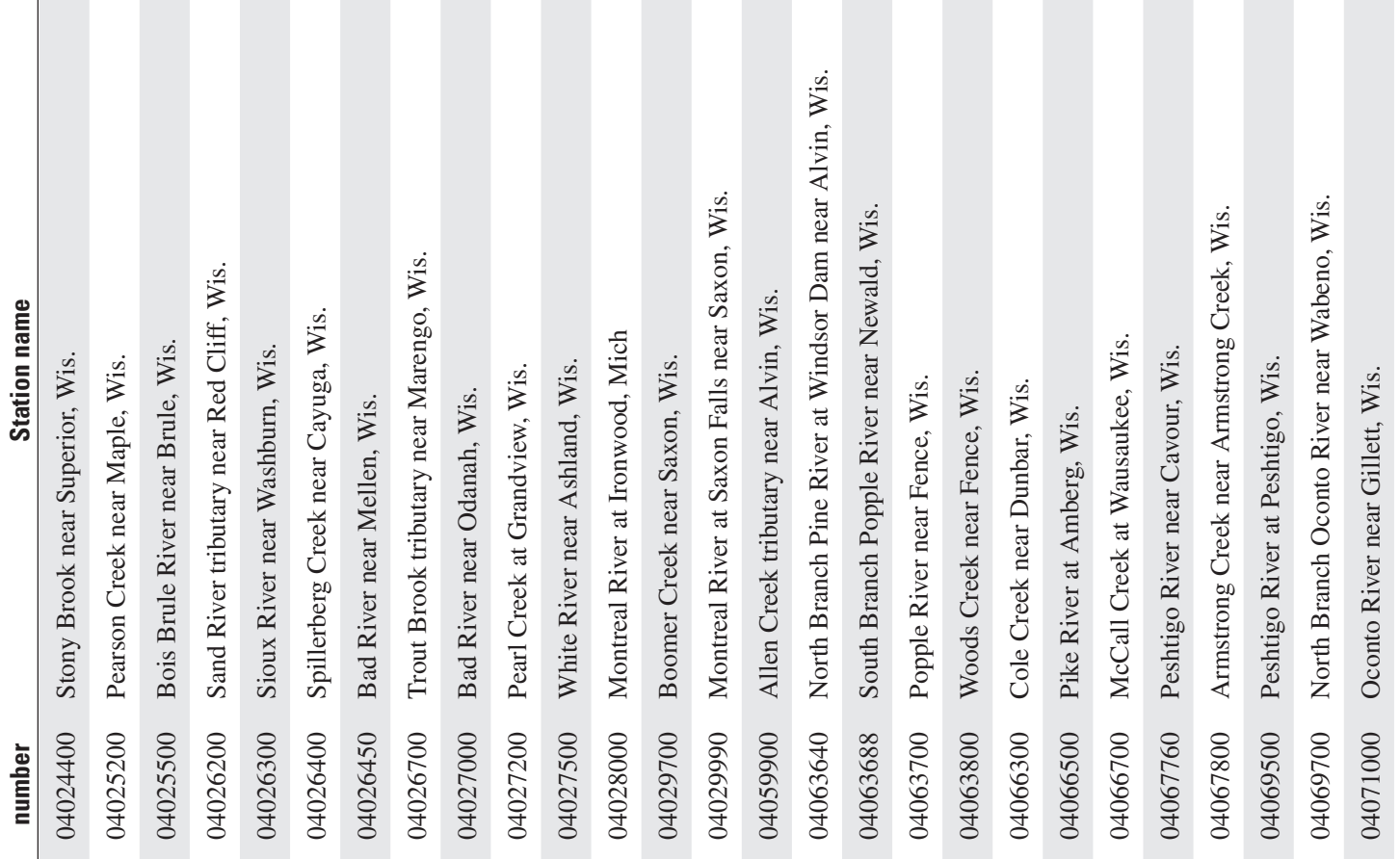




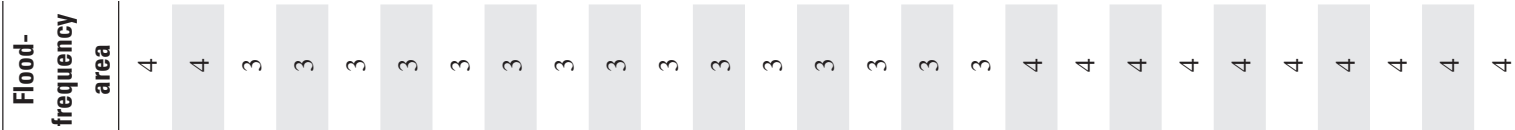

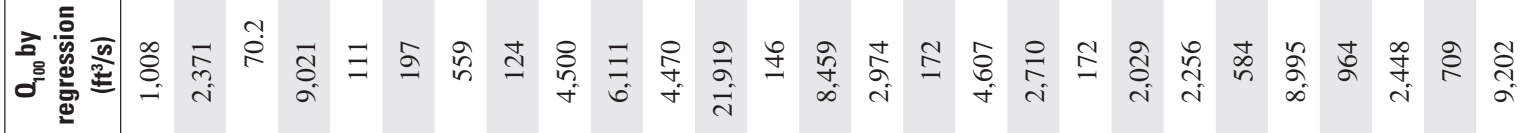

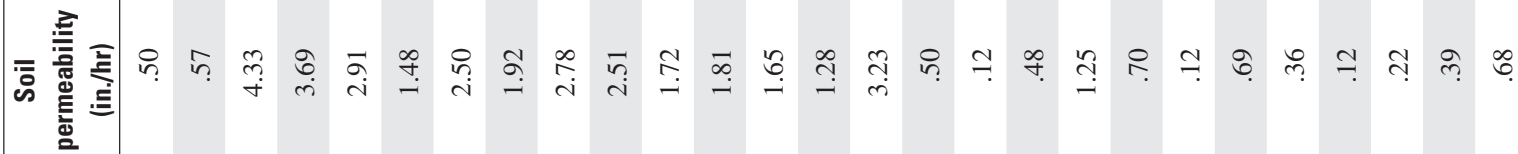

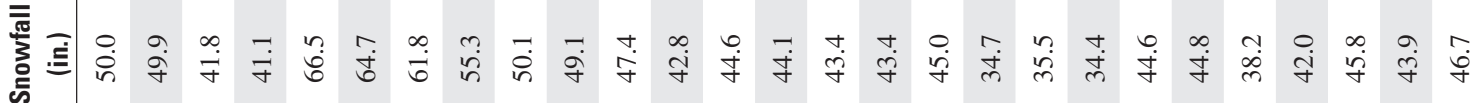

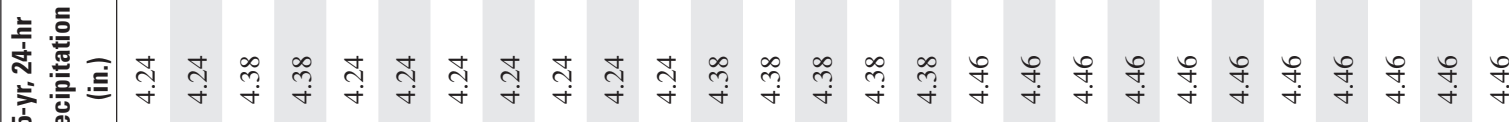

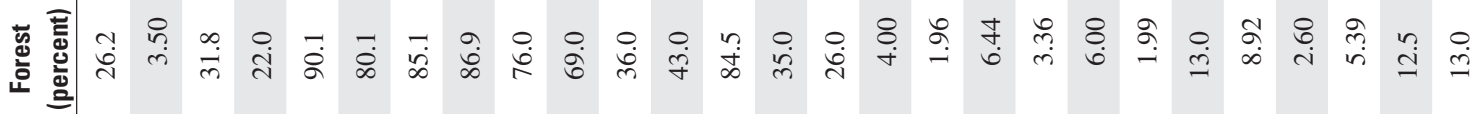

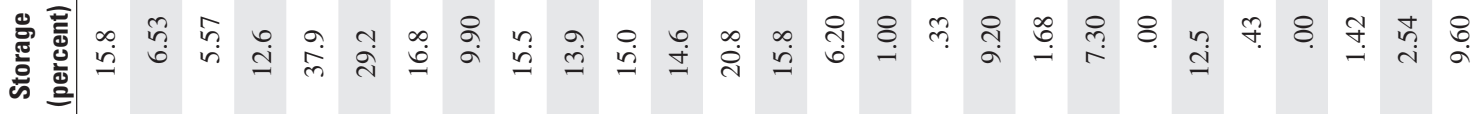

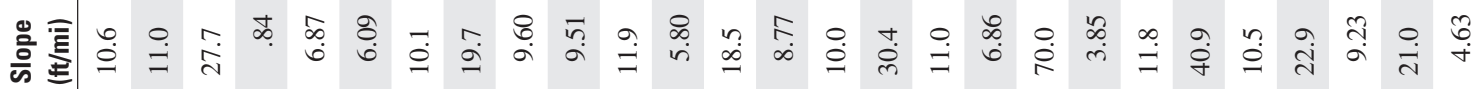
望

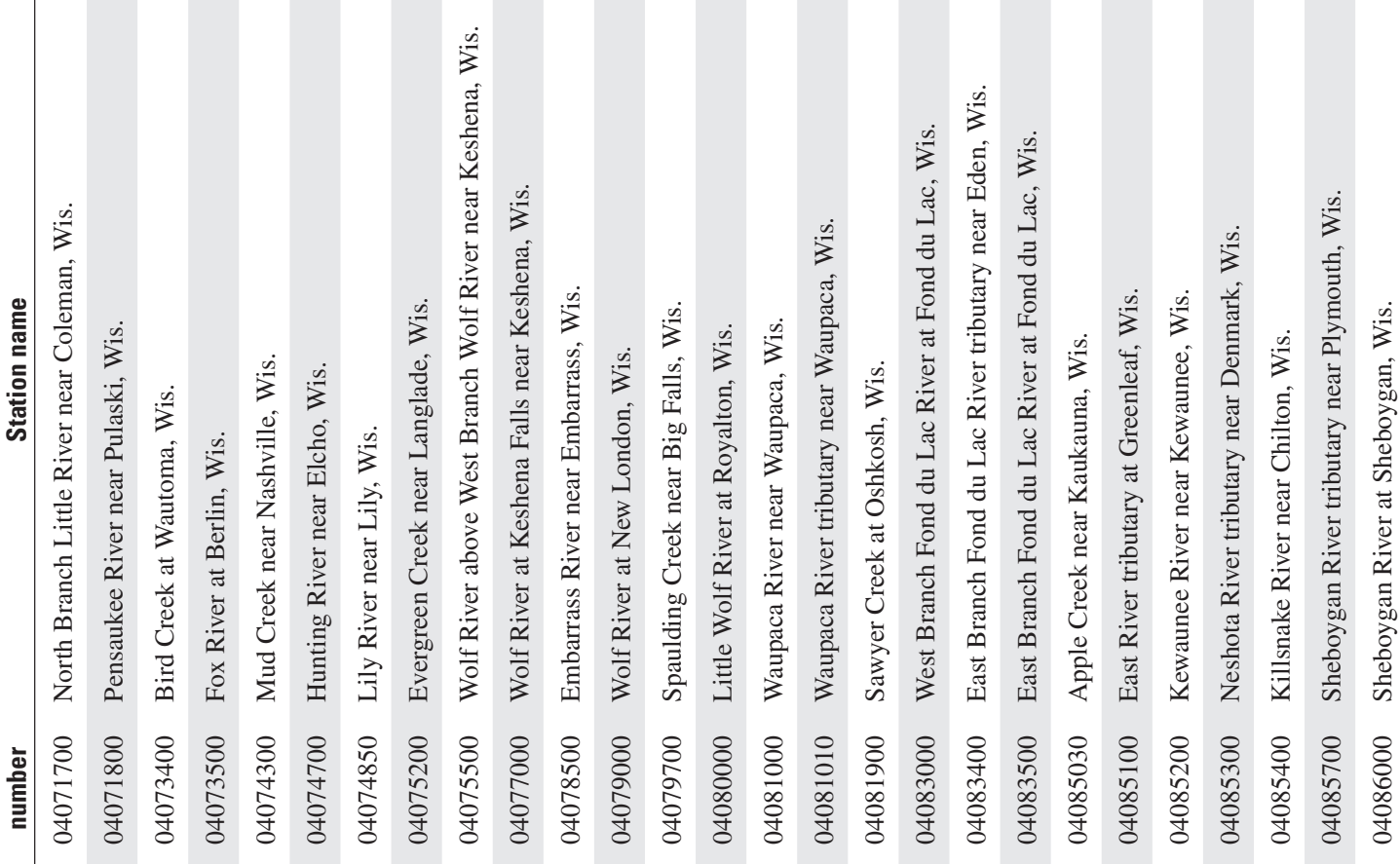




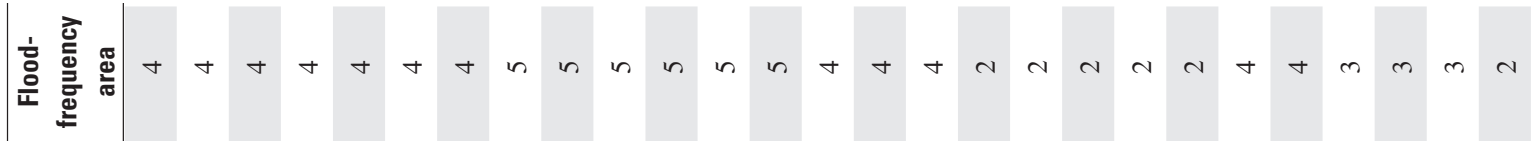

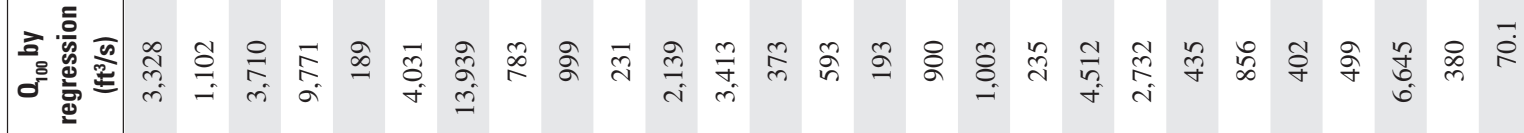

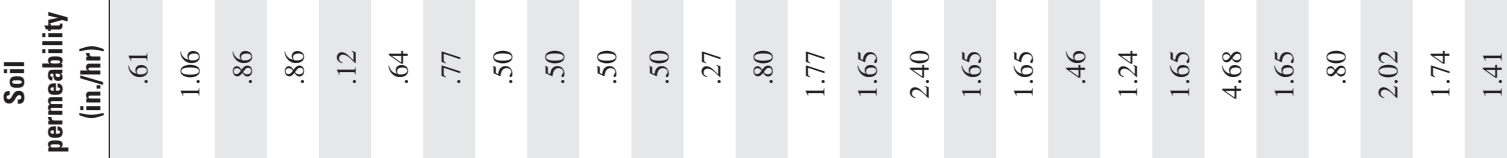

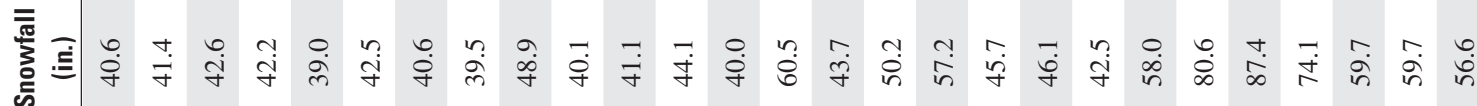

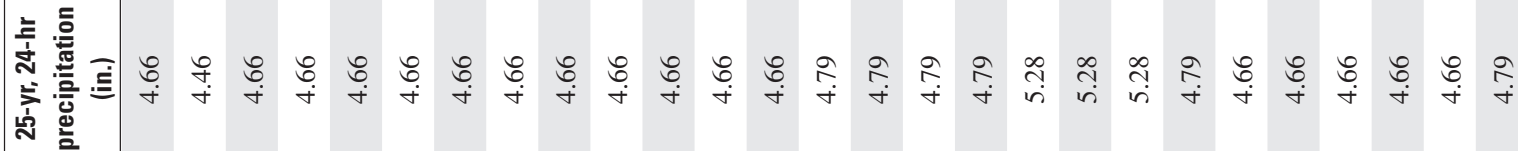

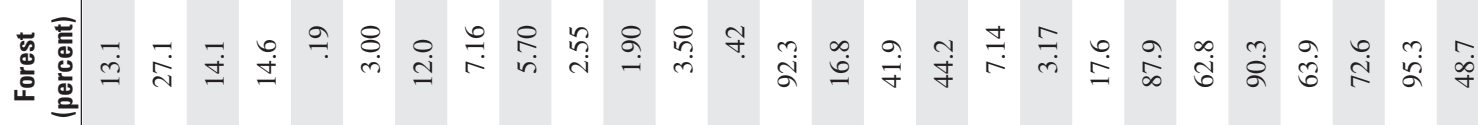

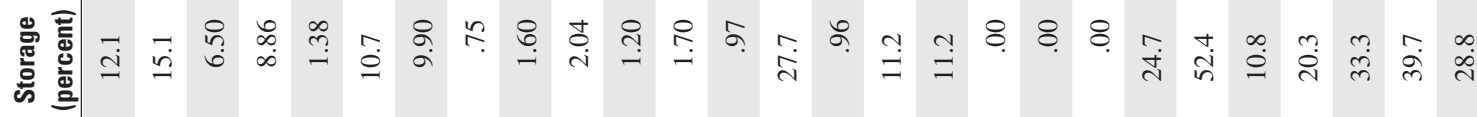

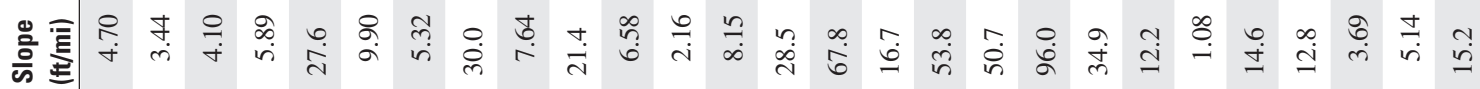

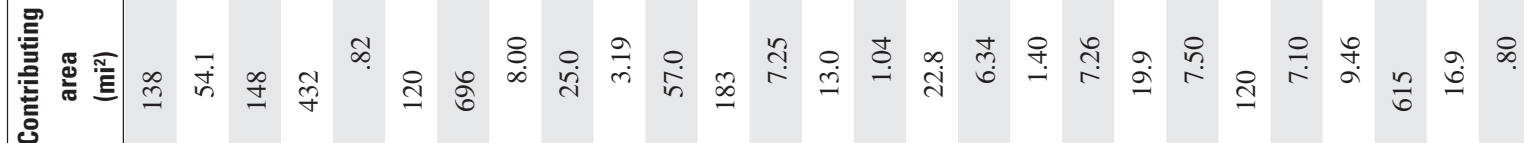

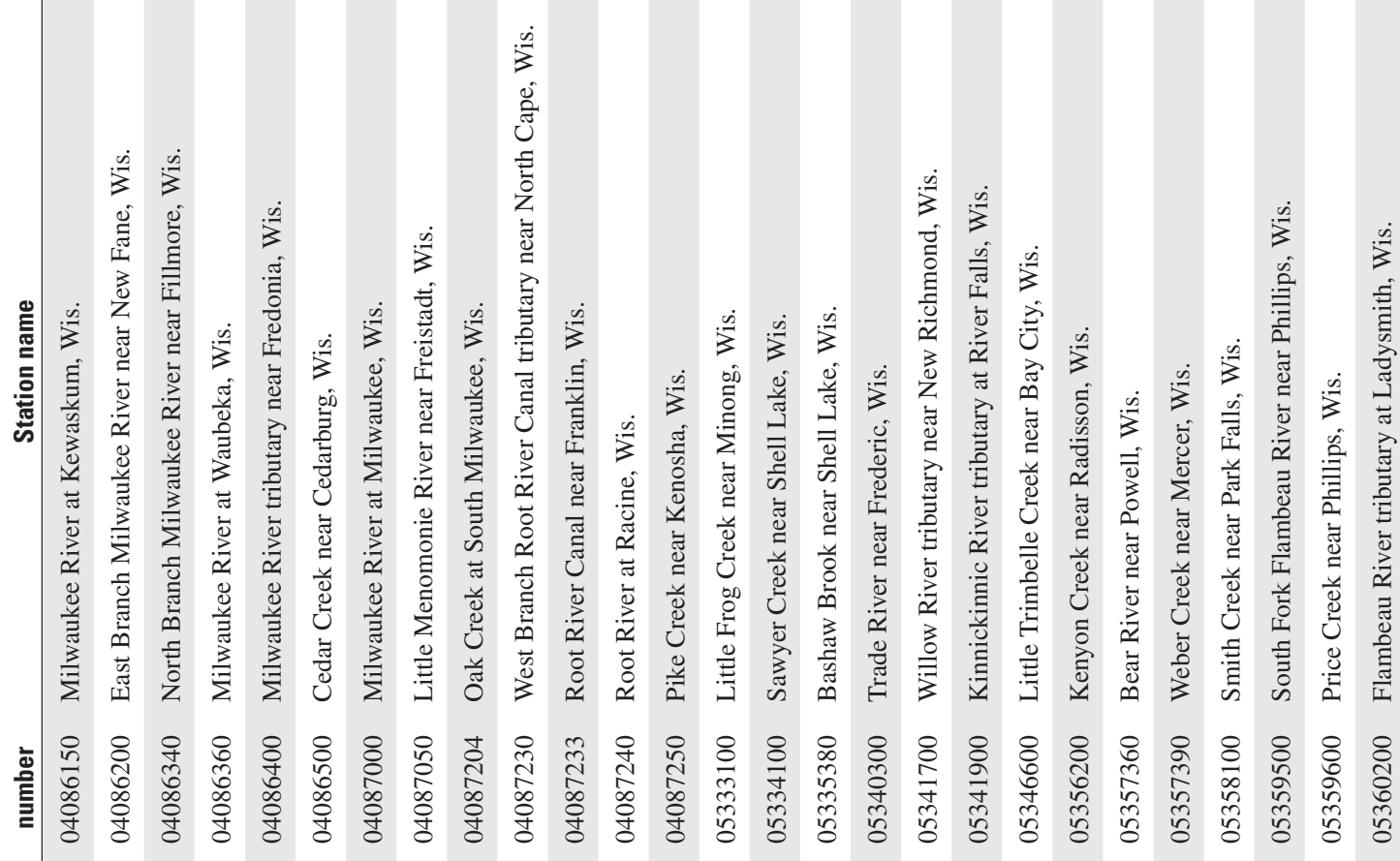




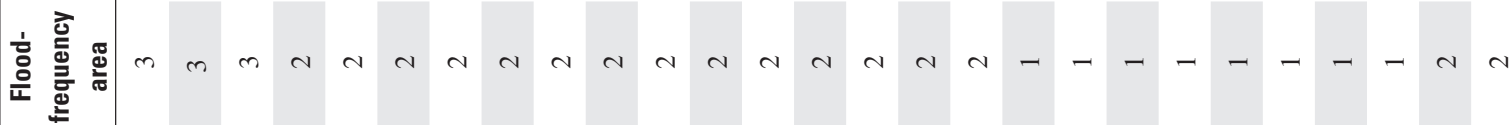

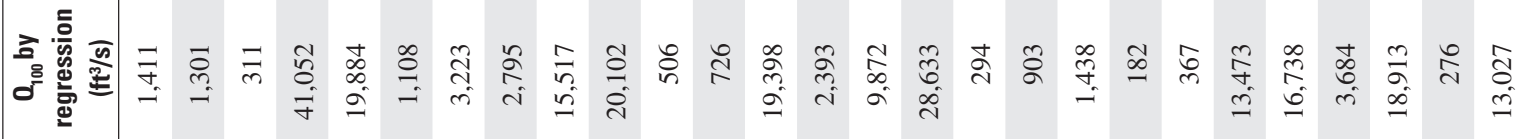
के

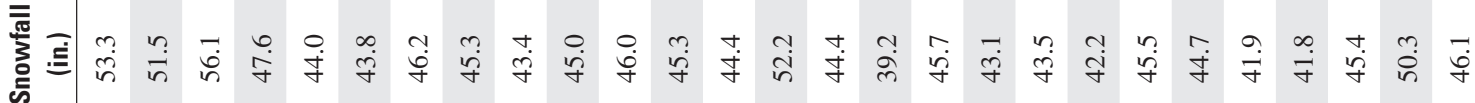

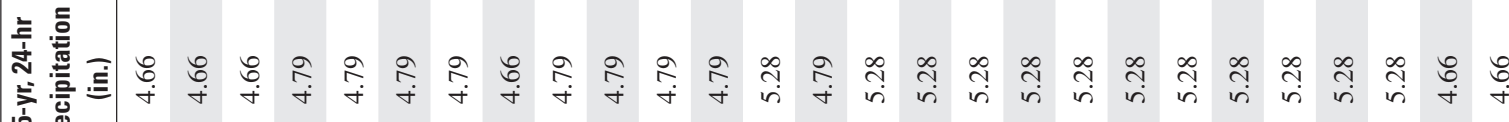
约

产

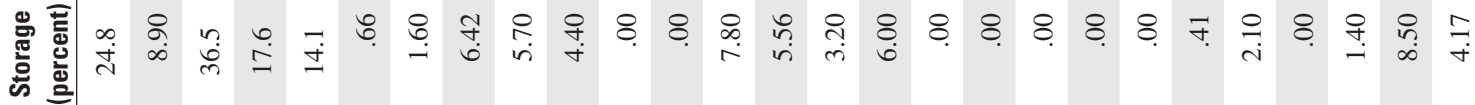

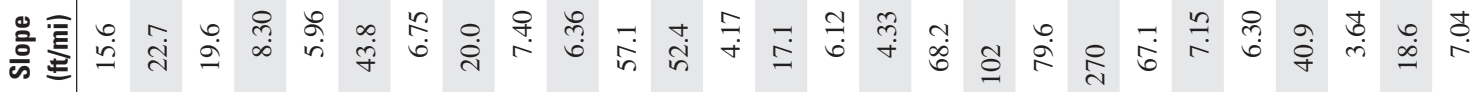

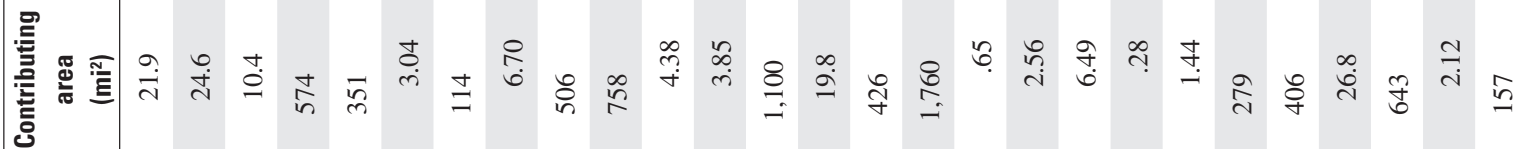

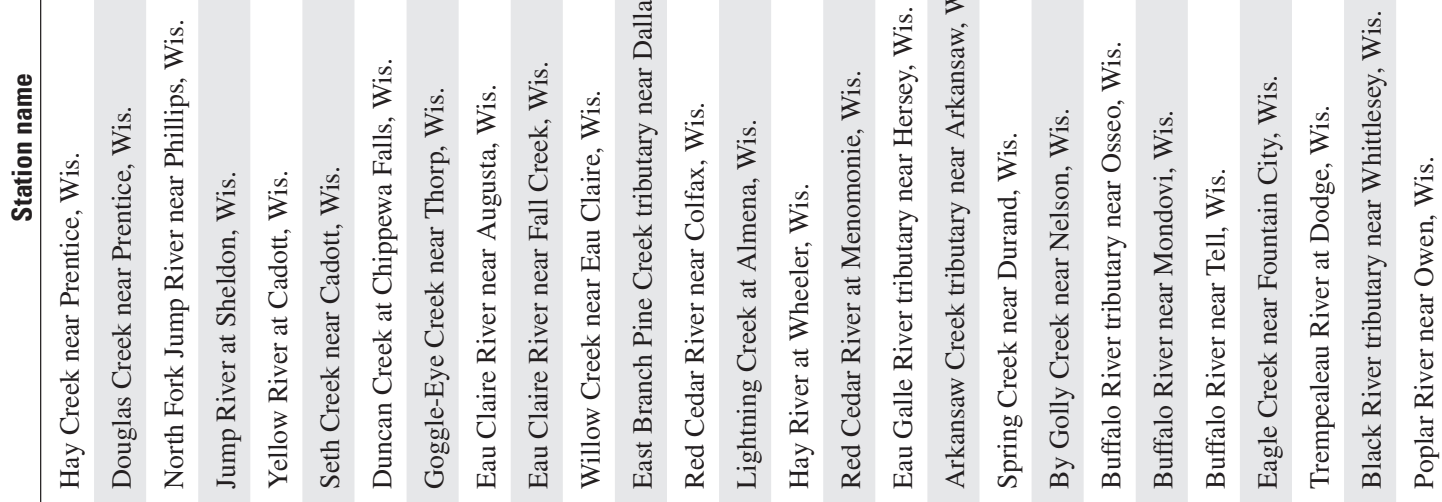

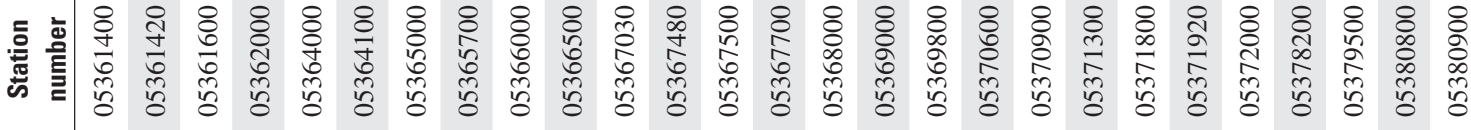




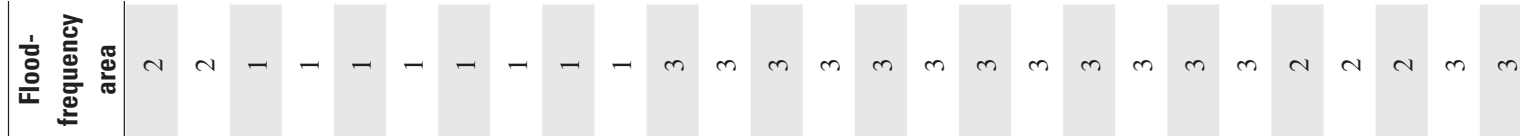

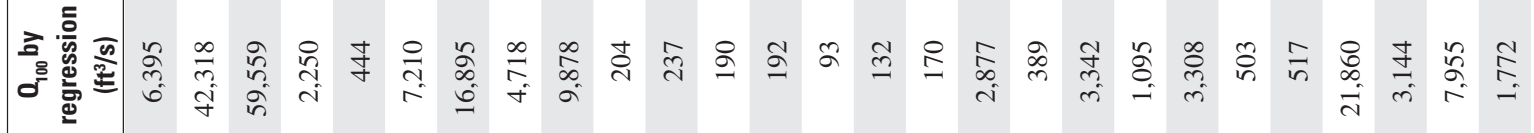

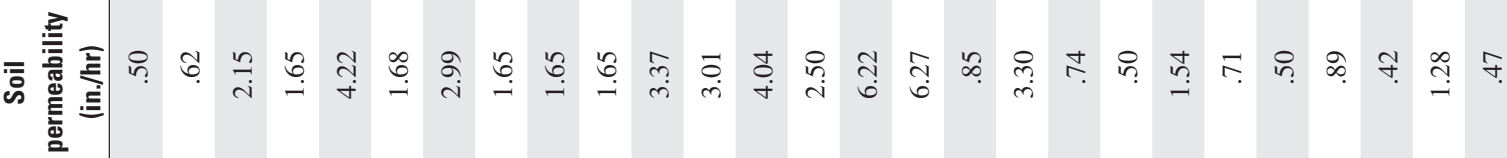

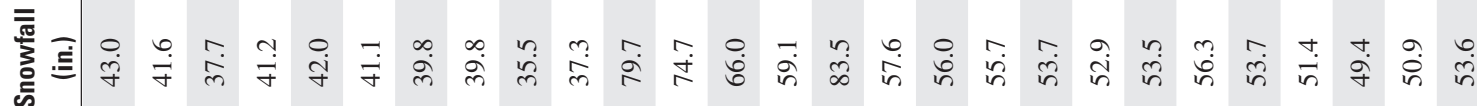

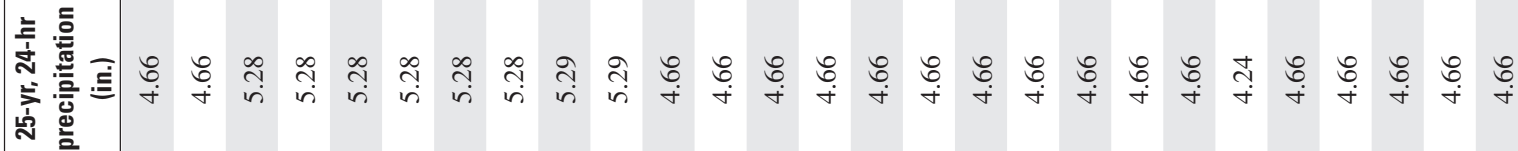

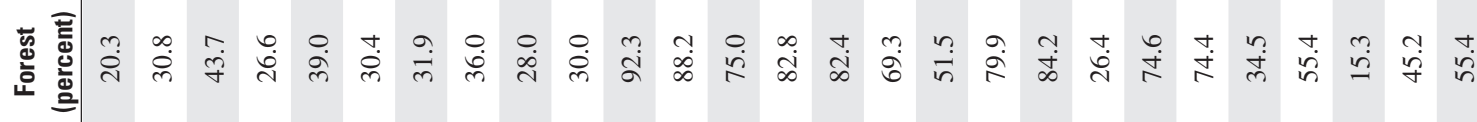

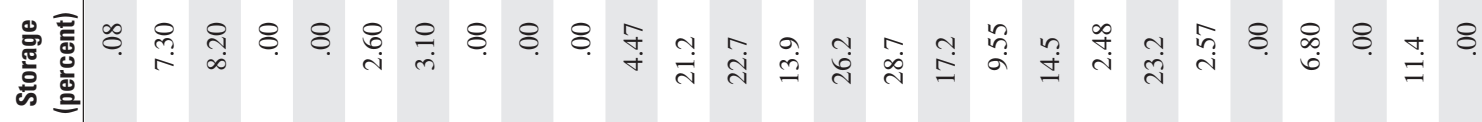

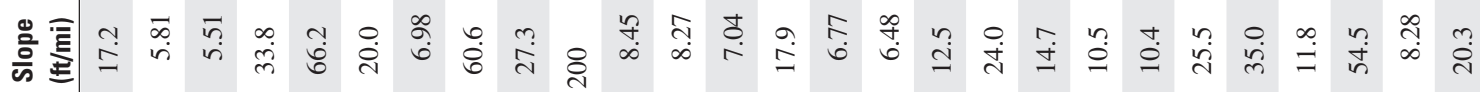

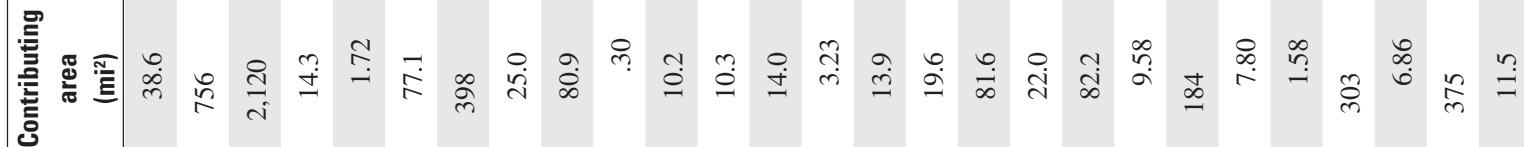

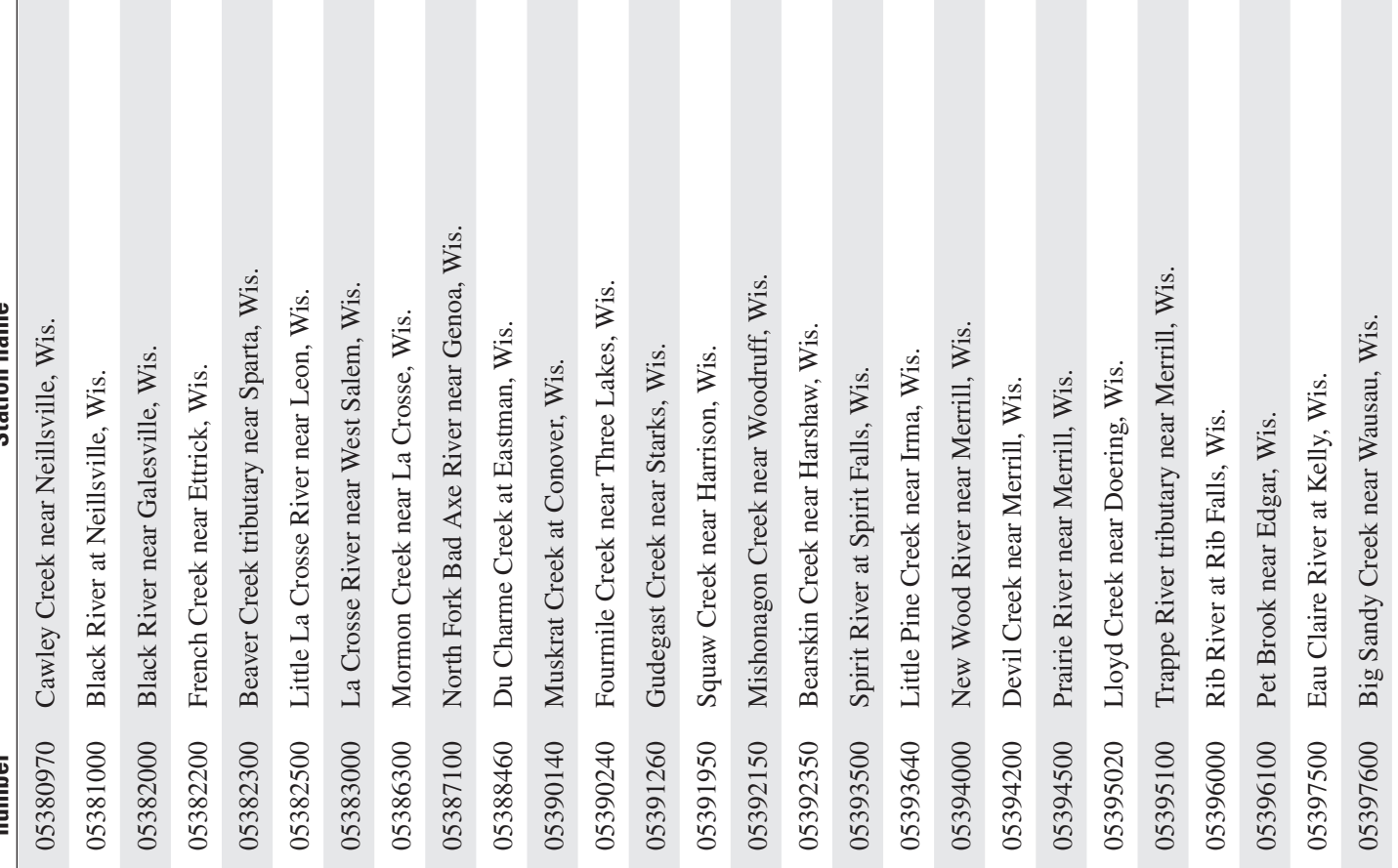




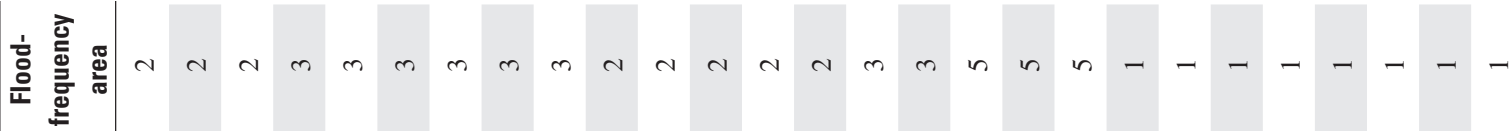

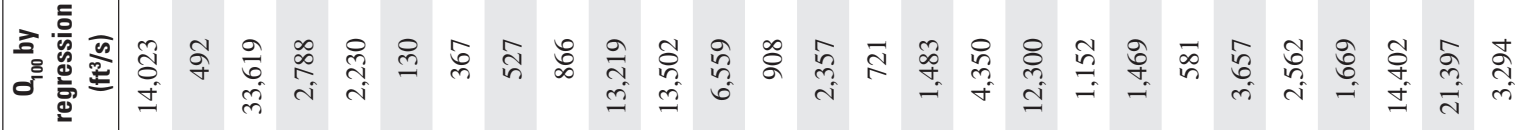

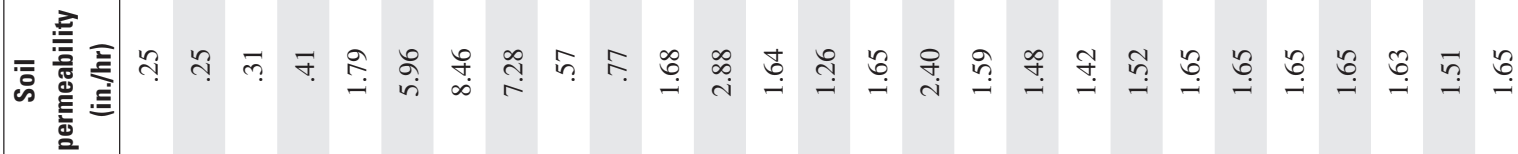

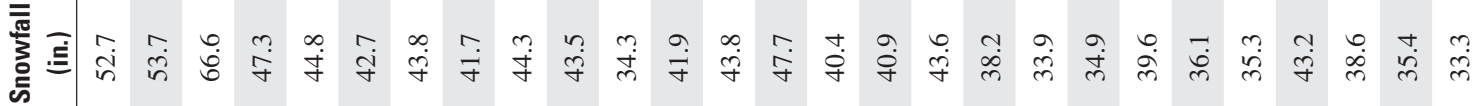

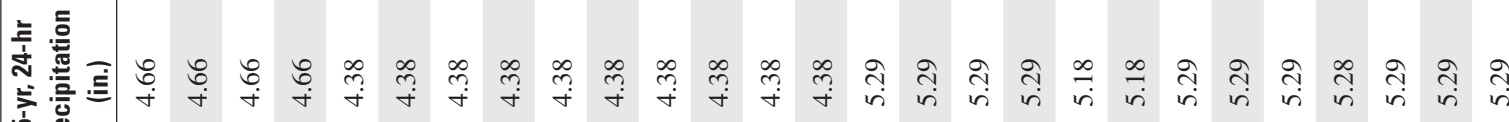
蛇

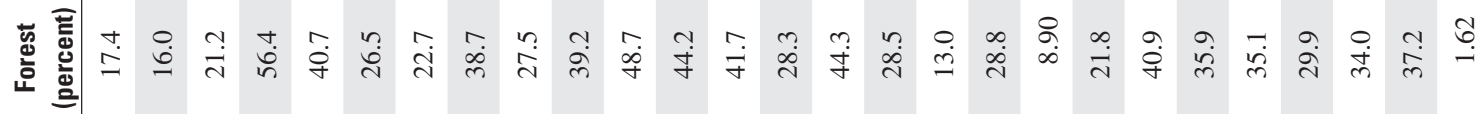

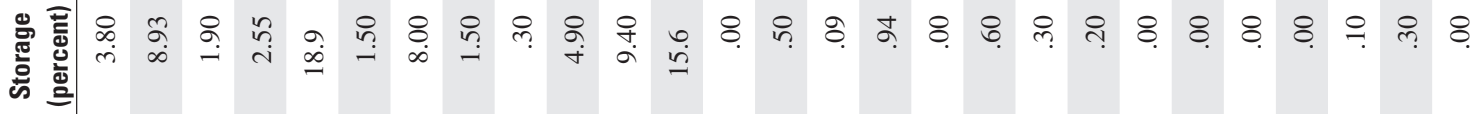

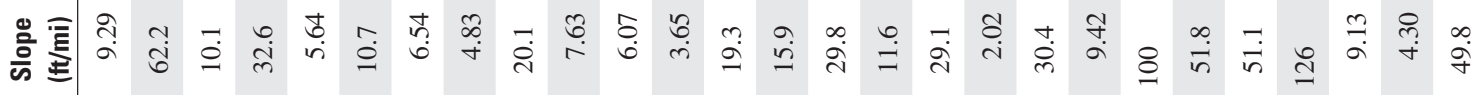

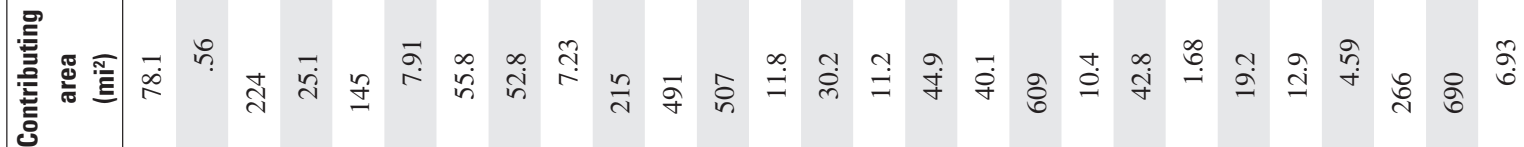

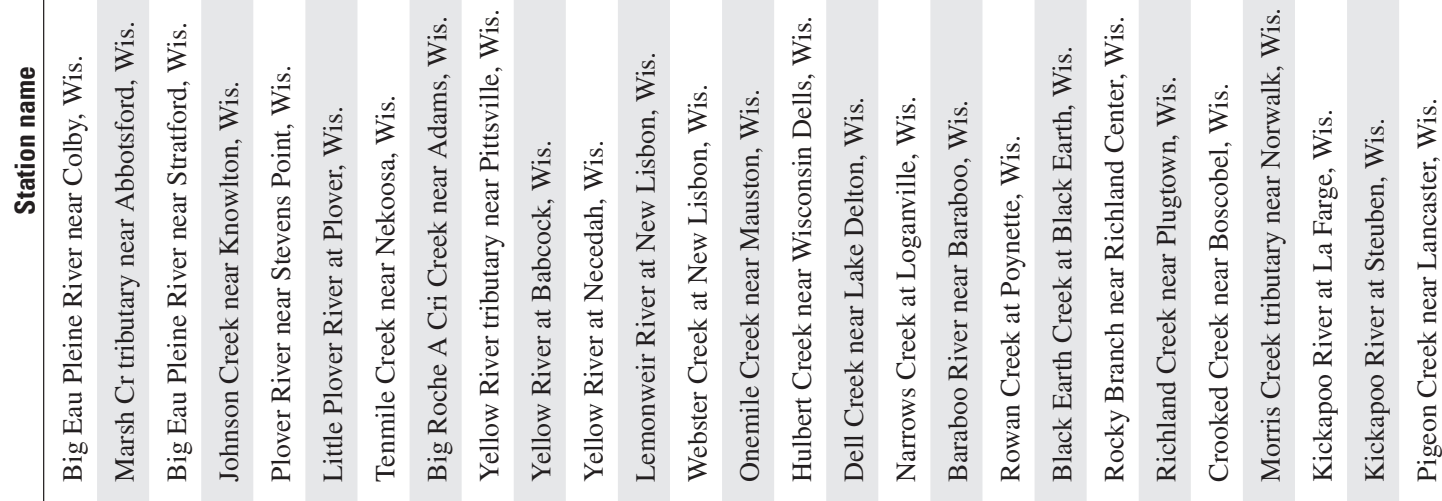

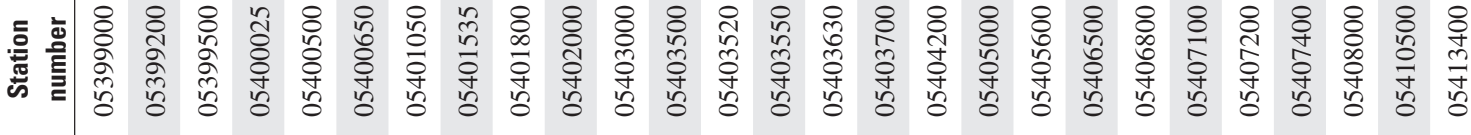




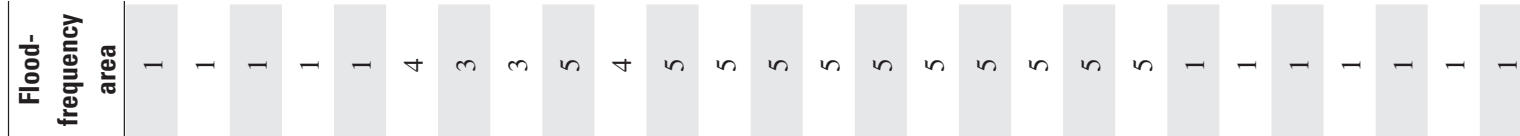

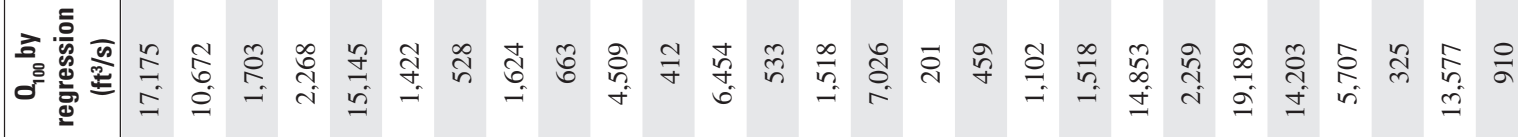

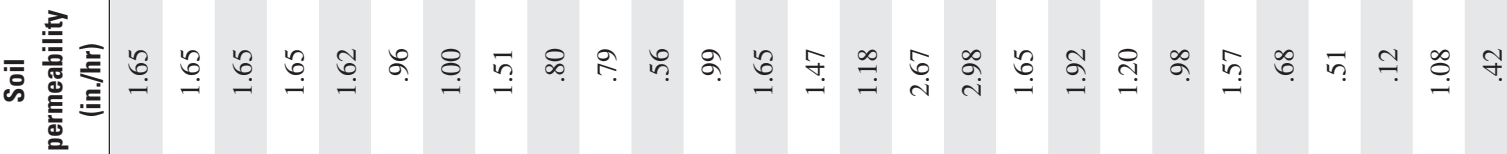

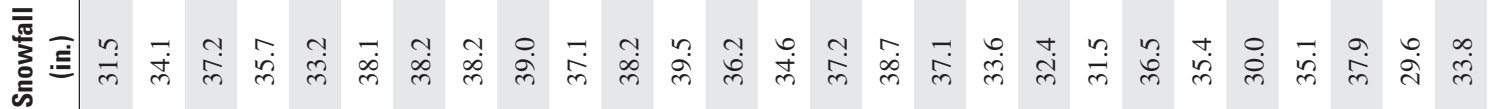

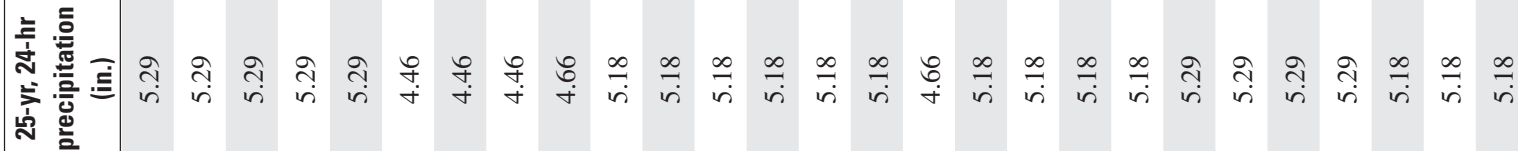

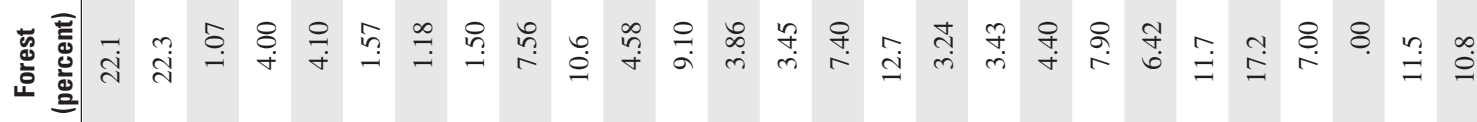

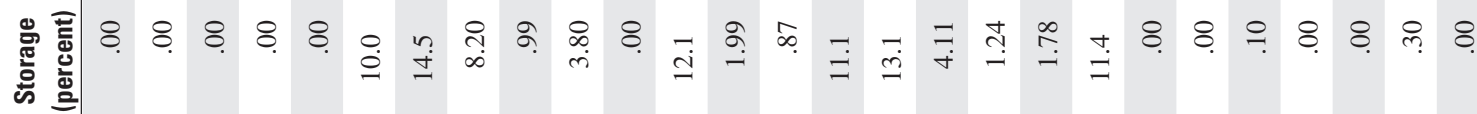

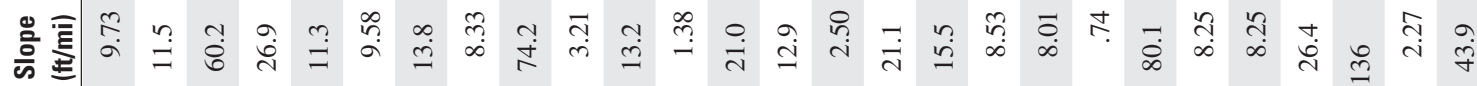

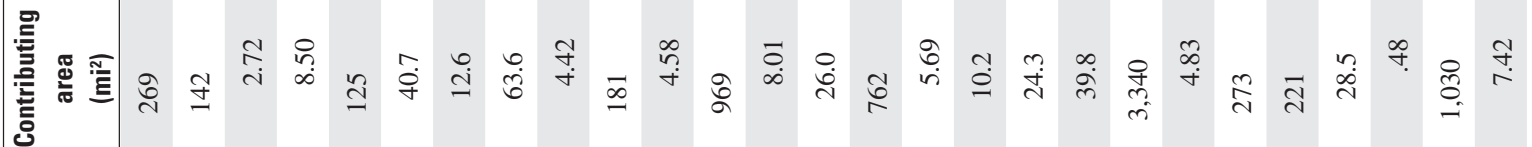

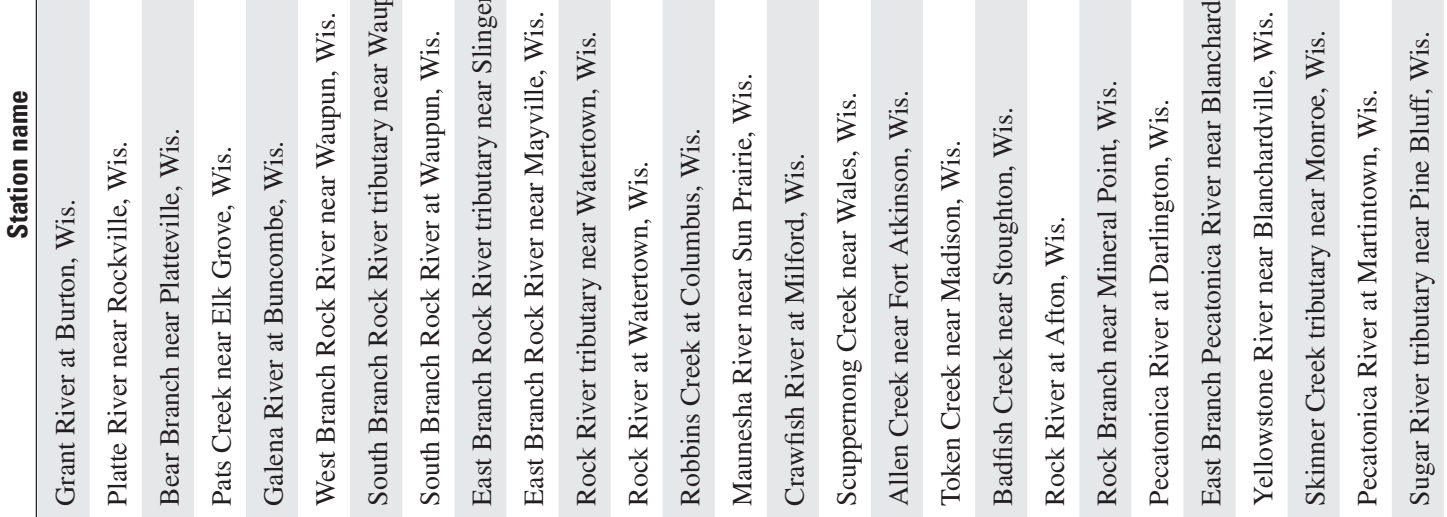

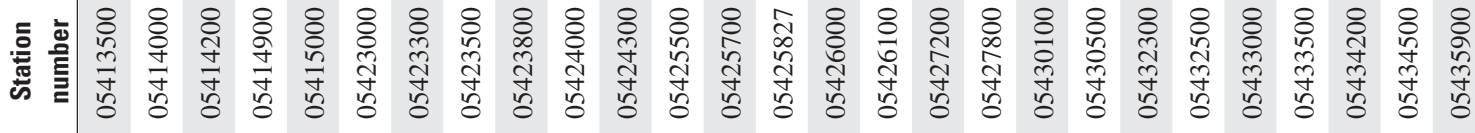




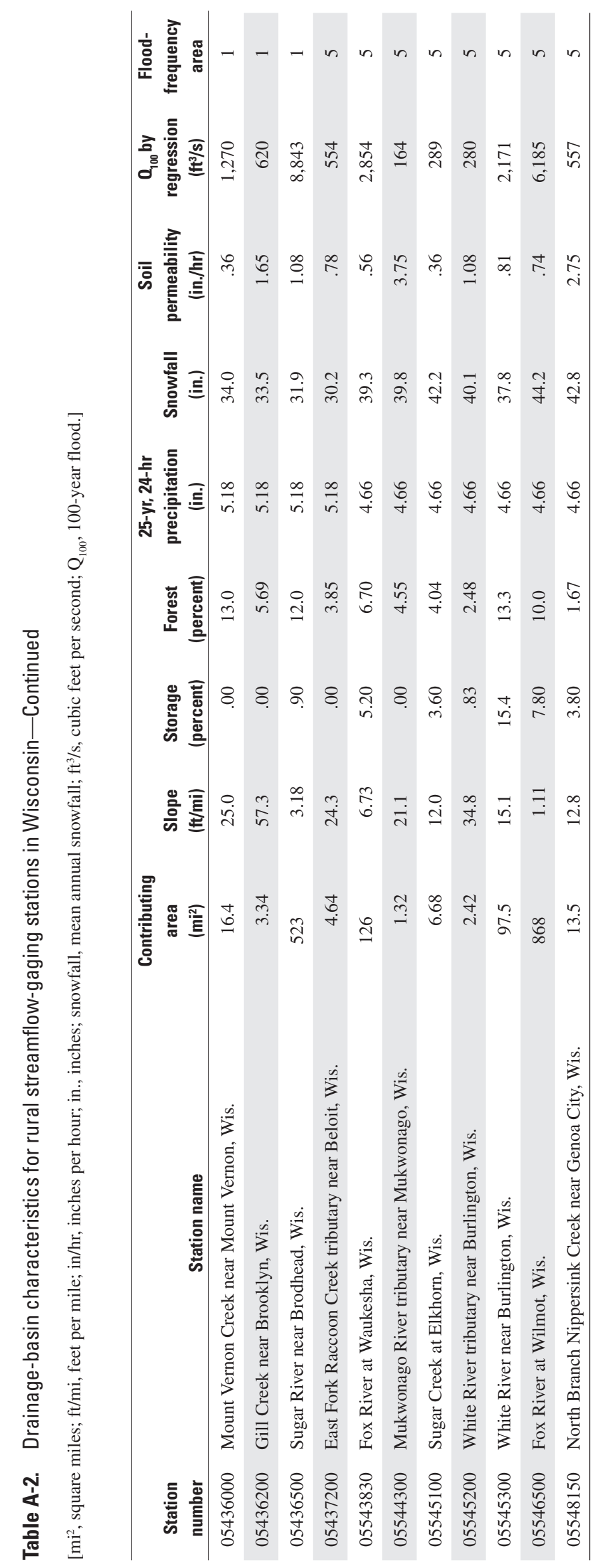

